\title{
Trace elements and oxidative stress in the Ark shell Arca noae from a Mediterranean coastal lagoon (Bizerte lagoon, Tunisia): are there health risks associated with their consumption?
}

\author{
Feriel Ghribi ${ }^{1}$ (1) - Jonathan Richir ${ }^{2,3} \cdot$ Safa Bejaoui ${ }^{1}$ - Dhouha Boussoufa ${ }^{1} \cdot$ Michel Marengo ${ }^{3,4} \cdot$ M $^{\prime}$ hamed El Cafsi $^{1}$. \\ Sylvie Gobert ${ }^{3,4}$
}

Received: 1 July 2019 / Accepted: 2 February 2020

(C) Springer-Verlag GmbH Germany, part of Springer Nature 2020

\begin{abstract}
The current study examined the concentrations of ten trace elements (TE) (nickel, chromium, cadmium, iron, zinc, manganese, aluminum, copper, selenium and lead) in the edible tissue of the Ark shell Arca noae (L. 1758) from a Mediterranean coastal lagoon, the Bizerte lagoon during 2013-2014. The analysis of several redox status biomarkers, metallothioneins (MTs), malondialdehyde (MDA), glutathione peroxidase (GPx), reduced glutathione (GSH) and acetylcholinesterase (AChE), was monitored as a response to TE bioaccumulation and environmental parameters variability. Significant differences $(p<0.05)$ were observed between mean seasonal TE concentrations in A. noae soft tissue. The highest TE concentrations in A. noae soft tissues were recorded during summer, which coincided with the increase of body dry weight (BDW) and the gonad index (GI). During this season, biomarker responses were enhanced, revealing significant increases of MTs, MDA and GSH levels as well as GPx activity in A. noae tissues, while a decrease of AChE activity was observed. The levels of TE analyzed in A. noae and several parameters used to assess the potential human risk (estimated weekly intake, target hazard quotient and target hazard risk) were lower than the permissible limits for safe seafood consumption. Consequently, this shellfish can be considered safe for human consumption. This preliminary study presents prospects for the valorization of this seafood product in Tunisia's food sector. It also gives basal information for future environmental assessment studies in which A. noae could be used as early warning tools in the field of biomonitoring programs and confirms the usefulness of biomarkers to monitor the health status of aquatic organisms.
\end{abstract}

Keywords Arca noae $\cdot$ Southern Mediterranean Sea $\cdot$ Trace elements $\cdot$ Contamination $\cdot$ Redox status $\cdot$ Human health

\section{Introduction}

Responsible editor: Cinta Porte

Electronic supplementary material The online version of this article (https://doi.org/10.1007/s11356-020-07967-2) contains supplementary material, which is available to authorized users.

Feriel Ghribi

ferielghribi@yahoo.fr

1 Laboratory of Ecology, Biology and Physiology of Aquatic Organisms, Faculty of Science of Tunis, University of Tunis El Manar, Tunis, Tunisia

2 Chemical Oceanography Unit (AGO), University of Liège, Quartier Agora, Sart-Tilman, Liege, Belgium

3 Laboratory of Oceanology, MARE Centre, University of Liège, Sart Tilman, Liege, Belgium

4 Station de recherche Sous-marines et Océanographiques (STARESO), Calvi, France
Estuaries and coastal lagoons known as highly productive areas are considered to be of extreme ecological and economic value (Bejaoui et al. 2017). Those ecosystems reinforce vital habitats for aquatic organisms and support many human activities such as fisheries, urban and industrial development and tourism. However, agricultural, urban and industrial discharges resulting from human activities can lead to high levels of pollution in these coastal habitats (Barhoumi et al. 2014; D'Adamo et al. 2008) that can affect living organisms and change their communities and the global ecological functioning of ecosystems (Warwick 2005). Among coastal lagoons, we quote the Bizerte lagoon (northern Tunisia), one of the first local ecosystems for fishing and mussels and other bivalve species production in Tunisia. Shellfish farming activities began in the 1950s with oyster farming (Crassostrea angulata). The Tunisian National Fisheries Office tried in 1958 to raise 
the oyster Ostrea edulis then, in 1972, the oyster Crassostrea gigas. Mytilus galloprovincialis culture, an indigenous species of the Bizerte lagoon, began in 1963 (Barhoumi 2014). Unfortunately, in recent decades, a sharp decline in its fisheries resources has been observed. The lagoon receives water laden with urban waste from neighboring cities as well as industrial waste. Industrial activities are highly developed near the lagoon and chronically expose aquatic organisms to xenobiotics such as organochlorine compounds (OCs), polycyclic aromatic hydrocarbons (PAHs), polychlorinated biphenyl (PCBs) and trace elements (TEs) (Trabelsi and Driss 2005).

Trace elements (TE) in coastal systems are a major problem as these environments, are frequently used for the removal and dilution of several wastes and thus contribute to the regular degradation of the environment because of their continuous inputs, persistence, toxicity and ability to concentrate in organisms through food web (Spencer et al. 2006; Wang et al. 2009; Ali et al. 2013). A wide variety of TE can attain coastal waters via numerous discharges ways such as industrial, urban and agricultural (Waeles et al. 2007; Viegas et al. 2009). The effect of toxic and persistent pollutants on the marine ecosystem can be expressed in terms of biochemical endpoints (e.g. biomarkers of toxicity) (Kamel et al. 2014; Mahmoud et al. 2010). Biomarker responses can be influenced by seasonal changes of both abiotic (environmental parameters and food availability) and biotic factors (metabolic activities such as reproductive cycle) (Bocchetti and Regoli 2006).

Bivalves, like any other marine organisms, can be exposed to many chemicals and can bioaccumulate xenobiotics. However, because of their resistance to harvesting stress and exposure to polluted environments, their sedentary nature and their natural abundance (Boussoufa, 2014), bivalves are designed as sentinel species and used in several biomonitoring programs (Bejaoui et al. 2017; Goldberg 1975; Richir et al. 2014).

The Bizerte lagoon inhabits a wide diversity of marine invertebrates, among them the valuable shellfish Arca noae. Like any benthic invertebrates, this mollusk may accumulate TE whether essential or not, which causes toxic effects above threshold levels. A. noae, an edible bivalve of the family Arcidae, lives attached on rocky grounds by solid byssus, from the low tide level to depth of about $120 \mathrm{~m}$ (Hrs-Brenko and Legac 1996). It is widespread in the Mediterranean Sea and the eastern Atlantic Ocean from Portugal to Angola (Gofas 2008). A. noae reaches $120 \mathrm{~mm}$ in length and lives up to 25 years (Puljas et al. 2015). Arca noae represents one of the important shellfish species that are commercially exploited throughout the eastern Adriatic Sea (Zupan et al. 2012) and reaches high market quotations in Croatia, Italy and Slovenia (Poutiers 1987).

Recent studies on $A$. noae from the eastern and central Adriatic coasts (Croatia) have shown that this shellfish may accumulate various trace elements, polychlorinated biphenyls and organochlorine pesticides (Ivankovic et al. 2016; Milun et al. 2016; Erk et al. 2018). Marine bivalves are known to pump large amounts of seawater and therefore come into contact with various chemicals in the water. Many chemical contaminants can cause potential toxicity, including inorganic chemicals (TE such as $\mathrm{Cd}$, As, $\mathrm{Hg}$ and $\mathrm{Pb}$ ) and organic compounds (polychlorinated biphenyls [PCB], dioxins and chlorinated hydrocarbons [PAHs]). These contaminants are accumulated in bivalve tissues both by absorption of the dissolved phase and by ingestion (Wang, 2009). Generally, the accumulation of TE and organics in mollusks is likely affected by environmental and seasonal/chemical factors and physiological processes (ODEQ, 2007).

Two other short reports published by Ozretic' et al. (1990) and Cuculic' et al. (2010) explored the possible correlation between some TE concentrations in A. noae tissues and the quality of its environment. All these studies concerned only A. noae populations from the Adriatic Sea. No data is available concerning the concentrations of TE in Ark shells from the Southern Mediterranean coasts. Similarly, there are little studies on biomarkers of oxidative stress in this species. De Clercq (2016) has reported the seasonal variation in metallothionein (MT) levels of A. noae from the Adriatic Sea. While, Peric et al. (2013) have demonstrated the effect of in vitro contamination with an organophosphorus pesticide (trichlorfon) on cholinesterase (ChE, EC 3.1.1.7) activity in the gills and adductor muscle of $A$. noae.

In the current work, the impact of each TE on consumer health is considered through several parameters: estimated weekly intake, target hazard quotient and target hazard risk. Considering that environmental parameters (temperature, salinity, $\mathrm{pH}$, chlorophyll $a$ and suspended particulate matter) may influence biological responses and TE bioaccumulation, we follow those parameters together with $A$. noae biotic parameters (reproductive cycle and body dry weight) for a proper interpretation of the data trying to answer the following questions: Does A. noae harvested from Bizerte lagoon accumulate trace element (TE) beyond threshold recommended for human consumption? Are they influenced by the physicochemical parameters of the environment and the reproductive cycle of the animal? Does the accumulation of these TE in A. noae soft tissue induce oxidative stress and disruption of the cell defense balance in these organisms?

In general, what is the state of health of $A$. noae in the Bizerte lagoon and possible consumption of this marine product doses poses risks to human health?

\section{Material and methods}

\section{Study area}

Bizerte lagoon is located on the northern coast of Tunisia $\left(37^{\circ}\right.$ $\left.11^{\prime} 20.4^{\prime \prime} \mathrm{N} 9^{\circ} 51^{\prime} 16.2^{\prime \prime} \mathrm{E}\right)$ in the Western Mediterranean Basin 
(Fig. 1). It covers an area of $128 \mathrm{~km}^{2}$ and has a mean depth of $7 \mathrm{~m}$, a maximum width of $11 \mathrm{~km}$ and a maximum length of $13 \mathrm{~km}$. It is connected to the Mediterranean Sea through a 6$\mathrm{km}$-long channel and communicates with the Ichkeul Lake $\left(110 \mathrm{~km}^{2}\right)$ through the 5-km-long and 3-m-deep Tinja channel (Béjaoui et al. 2008). This lagoon is located near several towns (Bizerte, Zarzouna, Menzel Abderrahmen, Menzel Jemil and Menzel Bourguiba), industrial facilities and agricultural fields that affect the area. Bizerte lagoon is a particular ecosystem regarding its hydrodynamic and biogeochemistry (Béjaoui et al. 2008). Five principal streams called "wadis," Tinja, Rharek, Ben Hassine, Haima and Guenniche, feed the lagoon non-permanently with freshwaters depending mainly on rainfall. The water supply of the "Rharek wadi" (Fig. 1), the nearest wadi to the sampling site, is characterized by a restricted catchment area $\left(8 \mathrm{~km}^{2}\right)$ and a low runoff coefficient $(0.66 \pm$ $0.08 \mathrm{~mm}^{3} /$ year). Nevertheless, the fairly high annual solid yield of this wadi $\left(1.46 \pm 0.32 \times 10^{3} \mathrm{~T} /\right.$ year $)$ results in very turbid waters inflows (Ben Garali 2009).

For this study, we monitored the southern less anthropized area of the lagoon. The sampling site $\left(37^{\circ} 09^{\prime} 03^{\prime \prime} \mathrm{N} 9^{\circ} 52^{\prime} 03^{\prime \prime} \mathrm{E}\right)$ was far from urban and industrial sources of contamination but remained influenced by agricultural inputs (Barhoumi et al. 2014; Mahmoud et al. 2010).

\section{Animal sampling and processing}

A total of 220 sexually mature $A$. noae of commercial size $(\sim 50 \mathrm{~mm})$ were collected the $15^{\text {th }}$ of each month by Scuba
Diving at about 3 to $5 \mathrm{~m}$ depth from October 2013 to August 2014. Samples were carried to the laboratory in a cool box. The shell length (SL), height (SH) and width (SW) were measured with a digital caliper to the nearest $0.1 \mathrm{~mm}$. Regardless of sex, for TE analysis, A. noae ( $n=10$ bivalves per month) were dissected and their whole body soft tissues stored at $-20{ }^{\circ} \mathrm{C}$ until analysis. For biomarker analysis, specimens ( $n=10$ bivalves per month) were dissected and their individual whole body soft tissues were frozen quickly in liquid nitrogen and stored at $-80^{\circ} \mathrm{C}$ until analysis.

\section{Environmental parameters}

Temperature $\left({ }^{\circ} \mathrm{C}\right)$, salinity $(\mathrm{S})$ and $\mathrm{pH}$ of Bizerte lagoon subsurface water were recorded using a WTW-197i multimeter (inoLab®). Subsurface water samples (2 L) were collected in a polyethylene bottle and transported to the laboratory in a cool box. Environmental parameters recording and water sampling were performed monthly between 8 and 9 a.m. local time from October 2013 to August 2014 and were concomitant to A.noae collection. Water samples were analyzed for suspended particulate matter (SPM, in $\mathrm{g} / \mathrm{L}$ ) and chlorophyll $a(\mathrm{Chl} a$, in $\mathrm{mg} / \mathrm{L})$ in the laboratory according to Aminot and Chaussepied (1983) with standard methods recommended for marine waters. Chlorophyll $a$ was extracted after filtration on Whatman GF/F filters with $90 \%$ methanol and concentrations were determined spectrophotometrically at 665 and $750 \mathrm{~nm}$. SPM dry weight was determined after filtration of $1 \mathrm{~L}$ of

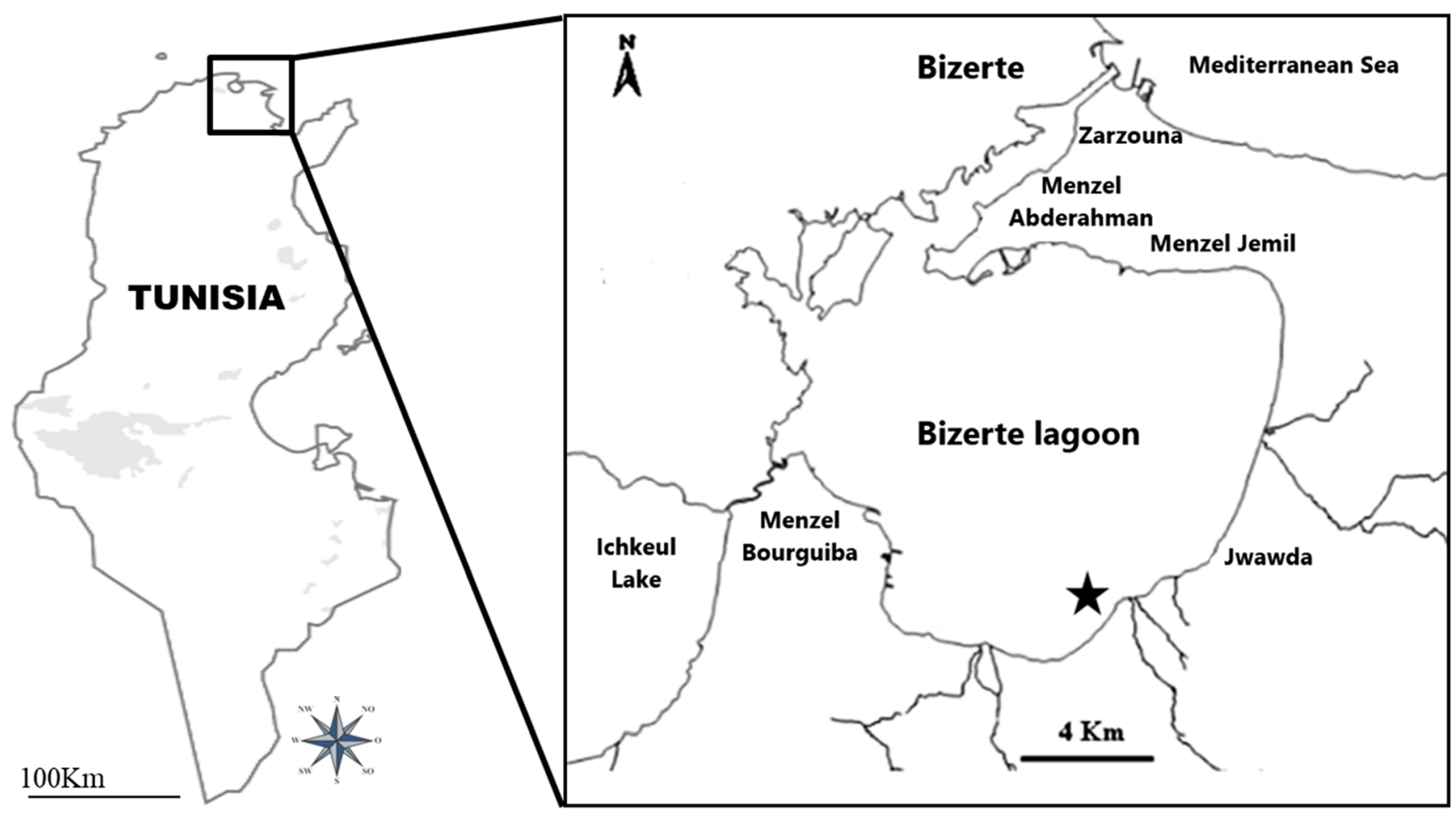

Fig. 1 Map of Bizerte lagoon (Northern Tunisia). The black full star in the Southern part of the lagoon shows the sampling site location 
seawater. Precipitation data during the year 2013-2014 was provided by the Tunisian Institute of Meteorology.

\section{Trace element analysis}

Only materials in ceramic, plastic and glass were used for sample treatment and storage. Soft tissues were rinsed with Milli-Q water to remove extraneous material. Whole soft tissues of 10 mollusks per sampling date were lyophilized separately. Dried specimens were ground to powder using an agate mortar and pestle. The wet and dry weight (before and after the drying process) of the samples was determined to the nearest $0.001 \mathrm{~g}$ using an electronic precision balance (KERN: ABJ 120-4M). According to the method described in Richir and Gobert (2014), dried powders ( $0.3 \mathrm{~g}$ of dried sample) were mineralized in Teflon bombs in a closed microwave digestion labstation (Ethos D, Milestone Inc.) using $2 \mathrm{ml}$ of nitric acid $\left(\mathrm{HNO}_{3}, 60 \%\right)$ and $1 \mathrm{ml}$ of hydrogen peroxide $(\mathrm{H} 2 \mathrm{O} 2,30 \%)$ as reagents (suprapur grade, Merck, Darmastadt, Germany). Digestates were diluted to an appropriate volume of $50 \mathrm{ml}$ prior to being analyzed. The concentrations of essential elements ( $\mathrm{Zn}, \mathrm{Fe}, \mathrm{Cu} \mathrm{Cr}, \mathrm{Mn}$ and $\mathrm{Se})$ and non-essential elements $(\mathrm{Al}, \mathrm{Pb}, \mathrm{Cd}$ and $\mathrm{Ni}$ ) were determined by inductively coupled plasma mass spectrometry (ICP-MS) using dynamic reaction cell (DRC) technology (ICP-MS ELAN DRCII, PerkinElmer Inc.). This instrument uses ion-molecule reactions to overcome spectral overlaps and requires selection of the appropriate reaction gas (Olesik and Jones, 2006): no reaction gas in standard mode (for ${ }^{111} \mathrm{Cd}$ and ${ }^{208} \mathrm{~Pb}$ ), NH3 (for ${ }^{27} \mathrm{Al},{ }^{52} \mathrm{Cr}$, ${ }^{54} \mathrm{Fe},{ }^{55} \mathrm{Mn},{ }^{60} \mathrm{Ni},{ }^{63} \mathrm{Cu}$ and ${ }^{66} \mathrm{Zn}$ ) or $\mathrm{H} 2\left(\right.$ for ${ }^{78} \mathrm{Se}$ ) in DRC modes. The purity of the chemicals used was verified by running several chemical blanks and no evidence of contamination was found. Analytical accuracy was checked by analyzing Certified Reference Materials: NIST 1566b (oyster tissue; mean recovery $=95 \pm 8 \%$ ) and NIST 2976 (mussel tissue; mean recovery $=106 \pm 7 \%$ ) from the American National Institute of Standards and Technology. The results obtained on the Certified Reference Materials were consistent with the certified values for all TE. For each element, detection limit (LD) and quantification limit (LQ) were calculated according to (Grinzaid et al. 1977; IUPAC et al. 1998; Currie, 1999), depending on their specific blank distribution. The trace element detection limits in $\mathrm{mg} \mathrm{kg}^{-1}$ dry weight (DW) were as follows: $\mathrm{Ni}=0.0142 ; \mathrm{Cr}=0.0030 ; \mathrm{Cd}=0.0005 ; \mathrm{Fe}=$ $0.0341 ; \mathrm{Zn}=0.0504 ; \mathrm{Mn}=0.0107 ; \mathrm{Al}=0.0808 ; \mathrm{Cu}=$ $0.0077 ; \mathrm{Se}=0.0423 ; \mathrm{Pb}=0.0025$. The limit of quantification (LQ) for each metal was also calculated $(\mathrm{Ni}=0.0468 ; \mathrm{Cr}=$ $0.0099 ; \mathrm{Cd}=0.0016 ; \mathrm{Fe}=0.1125 ; \mathrm{Zn}=0.1663 ; \mathrm{Mn}=0.0353$; $\mathrm{Al}=0.2664 ; \mathrm{Cu}=0.0254 ; \mathrm{Se}=0.1395 ; \mathrm{Pb}=0.0082)$. Concentrations were analyzed as TE concentrations on a dry weight basis ( $\mathrm{mg} / \mathrm{kg}$ Dw) and averaged by seasons: autumn (October-November 2013), winter (December 2013 to
February 2014), spring (March 2014 to May 2014) and summer (June 2014 to August 2014).

\section{Biomarker analysis}

Each whole animal soft tissue $(n=10)$ was thawed on ice and homogenized with an ultra Turrax ${ }^{\circledR}$ in phosphate buffer $(0.1 \mathrm{M}, \mathrm{pH}=7.4)$, then centrifuged at $9000 \times \mathrm{g}$ for $20 \mathrm{~min}$ at $4{ }^{\circ} \mathrm{C}$. Tissues homogenates aliquots were used for biomarker assays (malondialdehyde, glutathione peroxidase, reduced glutathione, metallothioneins and acetylcholinesterase). Biomarkers data were averaged according to the same seasons as for TE.

\section{Protein quantification}

Protein content ( $\mathrm{mg} / \mathrm{g}$ tissue) was determined in the whole soft tissue of A. noae according to Lowry et al. (1951), using bovine serum albumin (BSA) as standard $(0.5 \mathrm{mg} / \mathrm{ml})$. The protein content was used to quantify all biomarker responses.

\section{Malondialdehyde}

Malondialdehyde (MDA) level was determined spectrophotometrically according to Draper and Hadley (1990). Shortly, an aliquot of $0.5 \mathrm{ml}$ of soft tissue extract supernatant was blended with $1 \mathrm{ml}$ of trichloroacetic acid (30\%). After centrifugation at $3500 \times \mathrm{g}$ for $10 \mathrm{~min}, 1 \mathrm{ml}$ of thiobarbituric acid reagent $(0.67 \%)$ was added to $1 \mathrm{ml}$ of supernatant and heated at $100{ }^{\circ} \mathrm{C}$ for $10 \mathrm{~min}$. The mixture was then measured for absorbance at $532 \mathrm{~nm}$. The MDA values were calculated using 1,1,3,3-tetraethoxypropane as standard and expressed as nmoles/mg protein.

\section{Glutathione peroxidase}

Glutathione peroxidase (GPx) activity in the whole soft tissues was measured according to Flohe et al. (1984). About $200 \mu \mathrm{l}$ glutathione GSH $(4 \mathrm{mM})$ was incubated with $\mathrm{H}_{2} \mathrm{O}_{2}(5 \mathrm{mM})$ and determined using Ellman's reagent (DTNB: 5,5-dithiobis2 nitrobenzoic acid). The absorbance was measured at $412 \mathrm{~nm}$. This reaction is carried out by the presence of GSH as a substrate. As a result, the activity of GPx was expressed as nmoles of GSH/min/mg protein.

\section{Reduced glutathione}

Reduced glutathione (GSH) was quantified by the method of Ellman (1959). A volume of $500 \mu$ l of homogenate was added to $3 \mathrm{ml}$ of sulfo-salicylic acid (4\%). The mixture was then centrifuged at $1600 \times \mathrm{g}$ for $15 \mathrm{~min}$. An aliquot of $500 \mu \mathrm{l}$ of supernatant was taken and added to DTNB. The absorbance 
was measured at $412 \mathrm{~nm}$ after $10 \mathrm{~min}$. Total GSH was expressed as $\mu \mathrm{g} / \mathrm{mg}$ protein.

\section{Metallothioneins}

Metallothioneins (MTs) were estimated according to the spectrophotometric method of Viarengo et al. (1997) modified by Petrovic et al. (2001). An aliquot of $500 \mu$ of supernatant was mixed with absolute ethanol $(500 \mu \mathrm{l})$ and chloroform $(40 \mu \mathrm{l})$, followed by centrifugation at $6000 \times \mathrm{g}$ for $10 \mathrm{~min}$. After the addition of ethanol and incubation for $1 \mathrm{~h}$ at $4{ }^{\circ} \mathrm{C}$, pellets were washed with ethanol $(87 \%)$ and chloroform $(1 \%)$, then centrifuged for $10 \mathrm{~min}$. Pellets were suspended in $\mathrm{NaCl}(0.25 \mathrm{M})$ and EDTA $(1 \mathrm{mM})$. DTNB $(0.6 \mathrm{mM})$ dissolved in phosphate buffer $(\mathrm{pH}=8)$ was added to the sample. The absorbance was measured at $412 \mathrm{~nm}$. MTs concentration was expressed as $\mu$ moles of $\mathrm{GSH} / \mathrm{g}$ protein.

\section{Acetylcholinesterase activity}

Acetylcholinesterase (AChE) activity was measured in the whole soft tissues according to the method of Ellman et al. (1961) using acetylthiocholine iodide as a substrate, phosphate buffer $(0.1 \mathrm{M}$; pH=7.4) with DTNB (0.01 M). Enzyme activity was recorded over $5 \mathrm{~min}$ after addition of the substrate. AChE activity was expressed as nmoles/min/ mg protein.

\section{Human risk assessment analysis}

\section{Estimated weekly intake}

The daily intake of TE depends on both their concentrations in food and daily food consumption. In addition, the consumer body weight can influence the tolerance of contaminants (Chamannejadian et al. 2013). In this work, risk of TE intake was estimated by calculating the respective levels measured in A. noae, for a person weighing $60 \mathrm{~kg}$ and with a consumption rate of $154 \mathrm{~g}$ per week (a medium level mussel consumer, see Jovic and Stankovic 2014). The estimated weekly intake of each TE was determined using the following Eq. (1):

Estimated weekly intake : $\mathrm{EWI}=\left(\mathrm{C}_{\mathrm{m}} \times \mathrm{IR}_{\mathrm{W}}\right) / \mathrm{BW}$

where $\mathrm{Cm}$ is the TE concentration in $A$. noae soft tissue $\left(\mathrm{mg} / \mathrm{kg} \mathrm{wW}_{\mathrm{w}}\right), \mathrm{IR}_{\mathrm{w}}$ the weekly ingestion rate $(\mathrm{kg})$ and $\mathrm{BW}$ the body weight $(\mathrm{kg})$.

To assess public health risks, weekly Ark shell intakes were compared with the Provisional Tolerable Weekly Intake (PTWI) recommended by the joint FAO/WHO Expert Committee on Food Additives (FAO/WHO, 2011).

\section{Target hazard quotient}

The target hazard quotient (THQ) of a contaminant, defined as the ratio between the exposure and the reference dose (RfD) for that contaminant, expresses the risk of non-carcinogenic effects (Yi et al. 2011). If the ratio is less than 1, there will be no obvious risk (Chien et al. 2002). Conversely, an exposed population will experience health risks if the exposure dose is equal to or greater than the RfD, so the ratio above 1 (Marengo et al. 2018). Since the exposure to two or more contaminants may result in additive or interactive effects, we evaluated the total THQ (TTHQ) by summing THQ value of individual TE. The models for estimating THQ and TTHQ follow Eqs. (2) and (3):

$$
\begin{aligned}
& \mathrm{THQ}=\left(\mathrm{EF} \times \mathrm{ED} \times \mathrm{IR}_{\mathrm{d}} \times \mathrm{C}\right) /(\mathrm{RfD} \times \mathrm{BW} \times \mathrm{AT}) \\
& \mathrm{TTHQ}=\mathrm{THQ}(\mathrm{TE} 1)+\mathrm{THQ}(\mathrm{TE} 2) \ldots+\mathrm{THQ}(\mathrm{TE} \mathrm{n})
\end{aligned}
$$

where EF is the exposure frequency (365 days/year), ED is the exposure duration (70 years, average lifetime), $\mathrm{IR}_{\mathrm{d}}$ is the food ingestion rate $(0.0022 \mathrm{~kg}$ per day per person; Jovic and Stankovic 2014), RfD is the oral reference dose (Marengo et al. 2018; Nadal et al. 2008), BW is the average adult body weight $(60 \mathrm{~kg})$ and AT is the average exposure time for noncarcinogens (365 days per year x ED, assuming 70 years).

\section{Target cancer risk}

Target cancer risk (TR) indicates an incremental probability of an individual developing cancer over a lifetime due to exposure to a potential carcinogen (Saha et al. 2016).TR, derived from the intake of $\mathrm{Pb}$, was calculated since this element may promote both non-carcinogenic and carcinogenic effects depending on the exposure dose (Vieira et al. 2011). Cancer risk over a lifetime exposure to $\mathrm{Pb}$ was obtained using cancer slope factor (CPSo) provided by the USEPA (USEPA 2010). The model for estimating cancer risk follows Eq. (4):

$\mathrm{TR}=\left(\mathrm{EF} \times \mathrm{ED} \times \mathrm{IR}_{\mathrm{d}} \times \mathrm{C} \times \mathrm{CPSo}\right) /(\mathrm{BW} \times \mathrm{AT})$

where CPSo is the oral carcinogenic slope factor of 0.0085 $(\mathrm{mg} / \mathrm{kg} / \text { day })^{-1}$ for $\mathrm{Pb}$ from the Integrated Risk Information System (USEPA 2010) database.

Acceptable lifetime cancer risk levels range from $10^{-4}$ (indicating a probability of 1 in 10,000 chance of developing cancer) to $10^{-6}$ (indicating a probability of 1 in $1,000,000$ chance of developing cancer). The four TR categories are as follows: TR $\leq 10^{-6}=$ low, $10^{-4}$ to $10^{-3}=$ moderate, $10^{-3}$ to $10^{-}$ ${ }^{1}=$ high and $\geq 10^{-1}=$ very high (Marengo et al. 2018).

\section{Statistical analysis}

Data were analyzed using the software STATISTICA 8 (StatSoft Inc.) and GraphPad Prism 5 (GraphPad Software Inc.). 
The significance level was 0.05 for all statistical analyses. After testing for normality (Shapiro-Wilcoxon test) and homoscedasticity (Levene's test), significant differences between seasons for TE and biomarkers were determined with one-way analysis of variance (ANOVA) followed by a posthoc Tukey's test. If conditions for ANOVA were not fulfilled, non-parametric Kruskal-Wallis's test was used. Correlations between biochemical parameters, essential elements ( $\mathrm{Zn}, \mathrm{Fe}$, $\mathrm{Cu} \mathrm{Cr}, \mathrm{Mn}$ and $\mathrm{Se}$ ) and non-essential elements ( $\mathrm{Al}, \mathrm{Pb}, \mathrm{Cd}$ and $\mathrm{Ni}$ ) and biomarkers, were studied using non-parametric Spearman's rank correlation. Principal components analysis (PCA) was performed on a data matrix with seasons as objects and TE, biomarkers (MDA, GPx, GSH, MTs and AChE), gonad index (GI) and environmental parameters $(\mathrm{T}, \mathrm{S}, \mathrm{pH}$, Chl $a$ and SPM) as variables.

\section{Results}

\section{Shell biometry and environmental parameters}

During the study period, the shell length of $A$. noae ranged from $54.4 \pm 1.8$ to $56.0 \pm 0.5 \mathrm{~mm}$, the shell height from $29.0 \pm$ 1.3 to $31.2 \pm 0.4 \mathrm{~mm}$ and the shell width from $26.3 \pm 3.0$ to $28.3 \pm 0.4 \mathrm{~mm}$ (Table S1). Seasonal variations in water temperature $\left({ }^{\circ} \mathrm{C}\right)$, salinity, $\mathrm{pH}, \mathrm{Chl} a(\mathrm{mg} / \mathrm{L}), \mathrm{SPM}(\mathrm{g} / \mathrm{L})$ and rainfall $(\mathrm{mm})$ are presented in Table 1. Subsurface water temperature $(\mathrm{T})$ ranged from a minimum of $13.00 \pm 1.00\left({ }^{\circ} \mathrm{C}\right)$ in winter to a maximum of $27.33 \pm 1.15\left({ }^{\circ} \mathrm{C}\right)$ in summer. Salinity (S) varied from $34.57 \pm 1.32$ in winter to $38.20 \pm$ 0.62 in summer. Rainfall ranged from $1.07 \pm 1.15(\mathrm{~mm})$ in summer to $91.13 \pm 61.83(\mathrm{~mm})$ in winter. Two important peaks of Chl $a$ were measured during winter $(0.77 \pm$ $0.81 \mathrm{mg} / \mathrm{L})$ and spring $(1.41 \pm 0.95 \mathrm{mg} / \mathrm{L})$. As for the seasonal variation of SPM, two peaks were also observed, the first one in winter $(0.05 \pm 0.02 \mathrm{~g} / \mathrm{L})$ and the second one in spring $(0.04$ $\pm 0.01 \mathrm{~g} / \mathrm{L}$ ). $\mathrm{pH}$ values remained relatively constant during our sampling period, ranging from $8.05 \pm 0.07$ in autumn to 8.57 \pm 0.15 in summer. Significant positive correlations $(p<0.05)$ were observed between temperature and salinity (rho $=$ $0.876)$, between $\mathrm{pH}$ and both temperature $(\mathrm{rho}=0.680)$ and salinity (rho $=0.640$ ) and between $\mathrm{Chl} a$ and both temperature $($ rho $=0.270)$ and $\mathrm{pH}(\mathrm{rho}=0.250)$. SPM was significantly negatively correlated to $\mathrm{T}(\mathrm{rho}=-0.427), \mathrm{S}(\mathrm{rho}=-0.575)$ and $\mathrm{pH}($ rho $=-0.449)($ Table 2$)$.

\section{Trace element concentrations in A. noae soft tissue}

Mean seasonal TE levels ( $\left.\mathrm{mg} / \mathrm{kg}_{\mathrm{DW}}\right)$ determined in the whole soft tissue of $A$. noae are given in Table 3. TE concentrations in A. noae soft tissue decreased in the following order: $\mathrm{Zn}>\mathrm{Fe}$ $>\mathrm{Al}>\mathrm{Mn}>\mathrm{Cu}>\mathrm{Se}>\mathrm{Pb}>\mathrm{Cd}>\mathrm{Ni}>\mathrm{Cr}$. A. noae soft tissue contained more essential elements (e.g., $\mathrm{Zn}$ and $\mathrm{Fe}$ ) than toxic elements (e.g., $\mathrm{Pb}$ and $\mathrm{Cd}$ ). $\mathrm{Zn}$ concentrations were stable during seasons $(149.76 \pm 18.09$ to $172.45 \pm 13.91 \mathrm{mg} / \mathrm{kg} \mathrm{DW}$, $p>0.001)$. In contrast, concentrations of $\mathrm{Cu}, \mathrm{Cd}$ and $\mathrm{Ni}$ significantly differed $(p<0.001)$ between seasons, with minimal values recorded during autumn-winter $(3.78 \pm 0.16 ; 0.57 \pm$ 0.01 and $0.35 \pm 0.03 \mathrm{mg} / \mathrm{kg}$ Dw, respectively) and maximal values during summer $(6.37 \pm 0.40,0.91 \pm 0.22$ and $0.59 \pm$ $0.12 \mathrm{mg} / \mathrm{kg} \mathrm{Dw}$, respectively) (Table 3 ). Fe ranged from $128.41 \pm 22.97(\mathrm{mg} / \mathrm{kg} \mathrm{DW})$ during winter and $182.91 \pm$ $40.94(\mathrm{mg} / \mathrm{kg}$ Dw) during summer $(p<0.001)$. Same trends were observed for $\mathrm{Al}, \mathrm{Mn}, \mathrm{Pb}$ and $\mathrm{Se}$ concentrations $(p<0.001)$ with minimal values detected during winter $(20.83 \pm 3.14 ; 11.41 \pm 5.34 ; 0.49 \pm 0.09$ and $3.32 \pm 0.37 \mathrm{mg} / \mathrm{kg}$ DW, respectively) and maximal values during summer (117.02 $\pm 38.92 ; 19.60 \pm 5.75 ; 1.83 \pm 1.68 ; 4.74 \pm 0.14 \mathrm{mg} / \mathrm{kg}$ Dw, respectively). High levels of $\mathrm{Cr}$ were also observed during summer $(0.38 \pm 0.16 \mathrm{mg} / \mathrm{kg}$ Dw; $p<0.001)$ (Table 3$)$.

\section{Biomarker responses}

\section{Malondialdehyde levels}

MDA levels differed significantly $(p<0.001)$ between summer and the other season, from a minimum of $10.43 \pm$ $1.32 \mathrm{nmoles} / \mathrm{mg}$ protein in winter to a maximum of $33.73 \pm$ $9.25 \mathrm{nmoles} / \mathrm{mg}$ protein in summer, respectively (Fig. 2a).

\section{Glutathione peroxidase activity}

GPx activity increased seasonally and significantly $(p<0.001)$ from spring to summer, from a minimum of $2.25 \pm 0.39 \mathrm{nmoles} \mathrm{GSH} / \mathrm{min} / \mathrm{mg}$ protein to a maximum of $7.25 \pm 2.21$ nmoles GSH min/mg protein (Fig. $2 b$ ).

Table 1 Seasonal variation of water parameters (mean $\pm \mathrm{SD}$ ) of the studied site in the Southern part of Bizerte lagoon

\begin{tabular}{lllllll}
\hline & Temperature $\left({ }^{\circ} \mathrm{C}\right)$ & Salinity & Chlorophyll $a(\mathrm{mg} / \mathrm{L})$ & SPM $(\mathrm{g} / \mathrm{L})$ & $\mathrm{pH}$ & $\mathrm{Rainfall}(\mathrm{mm})$ \\
\hline Autumn 2013 & $20.00 \pm 2.83$ & $36.25 \pm 0.35$ & $0.63 \pm 0.28$ & $0.03 \pm 0.01$ & $8.05 \pm 0.07$ & $58.15 \pm 14.07$ \\
Winter 2014 & $13.00 \pm 1.00$ & $34.57 \pm 1.32$ & $0.77 \pm 0.81$ & $0.05 \pm 0.02$ & $8.10 \pm 0.10$ & $91.13 \pm 61.83$ \\
Spring 2014 & $17.33 \pm 3.06$ & $35.27 \pm 0.49$ & $1.41 \pm 0.95$ & $0.04 \pm 0.01$ & $8.23 \pm 0.06$ & $57.27 \pm 49.64$ \\
Summer 2014 & $27.33 \pm 1.15$ & $38.20 \pm 0.62$ & $0.57 \pm 0.28$ & $0.02 \pm 0.00$ & $8.57 \pm 0.15$ & $1.07 \pm 1.15$ \\
\hline
\end{tabular}




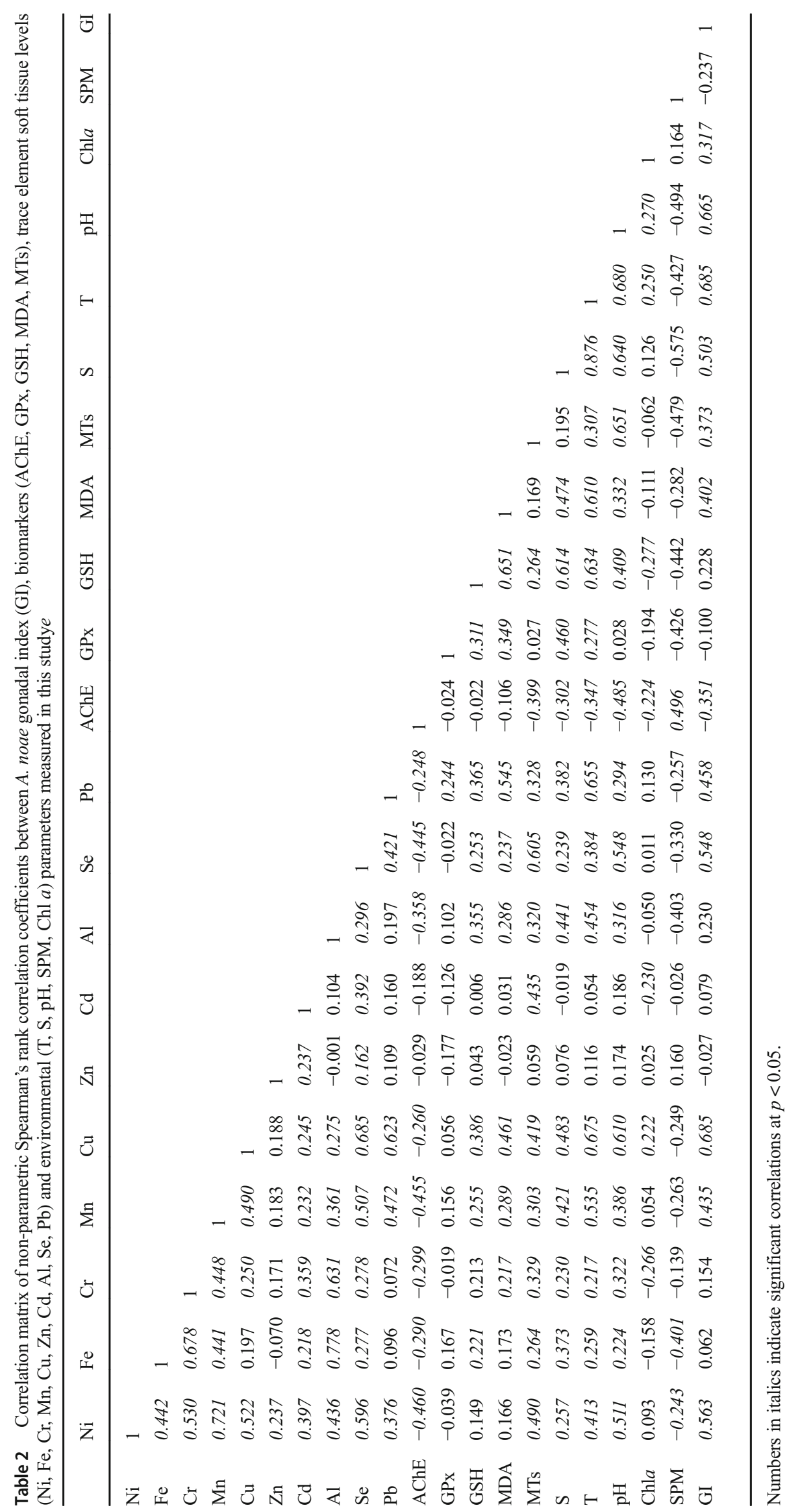


Reduced glutathione levels

GSH levels differed significantly $(p<0.001)$ between summer and the other season (Fig. 2c). The lowest values were recorded in winter $(1.21 \pm 0.44 \mu \mathrm{g} / \mathrm{mg}$ protein $)$ and the highest in summer $(5.15 \pm 2.62 \mu \mathrm{g} / \mathrm{mg}$ protein $)$.

\section{Metallothionein levels}

MTs levels increased seasonally and significantly $(p<0.001)$ from autumn to summer, from a minimum of $3.58 \pm$ $1.73 \mu$ moles of $\mathrm{GSH} / \mathrm{g}$ protein to a maximum of $10.72 \pm$ $1.23 \mu$ moles of GSH/g protein (Fig. 2d).

\section{Acetylcholinesterase activity}

AChE activity, as a neurotoxicity marker, ranged from 0.51 $\pm 0.05 \mathrm{nmoles} / \mathrm{min} / \mathrm{mg}$ protein in autumn to $0.18 \pm$ $0.10 \mathrm{nmoles} / \mathrm{min} / \mathrm{mg}$ protein in summer, respectively. AChE activity seasonal decreased significantly $(p<0.001)$ from autumn-winter to summer season (Fig. 2e).

\section{Human risk assessment analysis}

The results of the human risk assessment analysis are presented in Table 4. EWI values by seasons are compared with the recommend PTWI. EWI of $\mathrm{Cd}, \mathrm{Cr}, \mathrm{Cu}, \mathrm{Fe}, \mathrm{Pb}$ and $\mathrm{Zn}$ by a $60-\mathrm{kg}$ adult consuming $154 \mathrm{~g}$ of $A$. noae per week all over the year were all below the limit set by European regulations. THQ and TTHQ values for $A$. noae from Bizerte lagoon were lower than 1 . TR of $\mathrm{Pb}$ varied from $8.8 \times 10^{-7}$ to $1.43 \times 10^{-6}$ and did not exceed the cancer risk.

\section{Principal component analysis}

The first two factorial axes of PCA explained $67.82 \%$ of the total variance of the data set with TE levels, biomarkers measured in A. noae and environmental parameters (Fig. 3a). More precisely, the 1st factorial axis (Factor 1) explained $51.09 \%$ of the total variance with $\mathrm{Ni}, \mathrm{Cr}, \mathrm{Cu}, \mathrm{Al}, \mathrm{GSH}$, MTs, $\mathrm{S}, \mathrm{T}$ and $\mathrm{pH}$ contributing positively to this one. $\mathrm{Pb}$, GPx and MDA levels showed the highest weights in the 2nd factorial axis (Factor 2) that explained $16.73 \%$ of the total variance. The projection of seasons on the same factorial plane (1:2) showed a clear separation between summer and the other seasons. It was characterized by the highest values of all TE, oxidative stress biomarkers and abiotic parameters (T, $\mathrm{S}$ and $\mathrm{pH}$ ). It coincides also with the second phase of A. noae reproduction and the increase of gonad index (GI). While, autumn, winter and spring seasons were characterized by the highest AChE activity and the abundance of SPM and Chl $a$ levels in the lagoon waters (Fig. 3b). 


\section{Discussion}

This study investigated for the first time the concentrations of TE and biomarker responses in the Ark shell A. noae collected seasonally from Southern Mediterranean coasts (Bizerte lagoon, Tunisia). Our scientific approach relied on multiple variables: TE, biomarkers of oxidative stress and environmental parameters at different periods of the species reproductive cycle. This study further assessed the risk linked to the consumption of this shellfish product by local populations.

Seasonal monitoring of TE levels in A. noae soft tissue showed significant differences $(p<0.05)$, revealing a large accumulation of essential TE than the toxic ones $(\mathrm{Pb}$ and $\mathrm{Cd})$. This trend could be justified either by the fact that essential elements like $\mathrm{Zn}$ and $\mathrm{Fe}$ are fundamental for most living organism's physiological processes (spermatogenesis, enzymatic activity etc.) (Pinta 1980; Yamaguchi et al. 2009) or either by their bioavailability in the surface sediments of Bizerte lagoon as reported by Zaaboub et al. (2015) and Brik et al. (2018). Positive and significant correlations $(p<0.05)$ between TE concentrations in A. noae were observed (Table 2). These correlations probably reflected their similar bioaccumulation indicating a common source of inputs, derived from the ubiquitous enhances of human activities in the neighboring region. Indeed, interactions in TE bioaccumulation models can occur when they are in a mixture as in wastewater effluents or other sources of releases (George et al. 2013). This inter-elemental relationship for essential and non-essential elements accumulated in A. noae indicates strongly a similar pathway of metal uptake. TE levels in A. noae soft tissue were significantly higher in summer compared with other seasons $(p<0.05)$. This increase in summer could be due to the possible increase of TE concentrations in the lagoon waters, by runoff from adjacent farmland since A. noae sampling site is located near the agricultural area of Bizerte city. However, this hypothesis is rejected given the drought and the scarcity of rain during summer. Data precipitation showed a lack of rain during summer 2014 in Bizerte (see Table 1). Therefore, we suppose that the increase of TE levels in A. noae tissues in summer resulted from the evaporation process of Bizerte lagoon surface water. According to Béjaoui et al. (2017), water evaporation in Bizerte lagoon increases from $6.8 \mathrm{Mm}^{3}$ in winter to about $35.8 \mathrm{Mm}^{3}$ in summer. It has been previously reported that water evaporation and the increase of salinity could strongly lead to TE accumulation in bivalves during summer season (Staines-Urías et al. 2009; Strižak et al. 2014; Edokpayi et al. 2016). It has been shown in several studies that concentrations of the majority of TE emissions from anthropogenic activities accumulate in the river and oceanic sediments (Adamo et al. 2005; Bejaoui et al. 2018). The high evaporation rate might contribute to the concentration of TE in the water column, their deposition on the surface sediments and consequently on the bivalves tissues
(Bejaoui et al. 2018). Indeed, benthic invertebrates can absorb metals directly from sediments, either by absorption/ adsorption from interstitial water or by direct ingestion, which will potentially affect other species through the food chain (Adamo et al. 2005; Chen et al. 2007). TE released from sediments via natural or anthropogenic processes will have harmful effects on the health of live species in these ecosystems (Phuong, 2014).

According to Frías-Espericueta et al. (1999), the main factors influencing TE levels in bivalves are the environmental factors (temperature, salinity, $\mathrm{pH}$ etc.), which affect their speciation (dissolved and/or particulate) in the water column. The accumulation of TE in marine organisms is largely influenced by speciation, i.e. the chemical form in which it exists (Amiard et al. 1987; Chiffoleau et al. 2001). In this study, most TE showed positive $(p<0.05)$ correlations with $\mathrm{T}, \mathrm{S}$ and $\mathrm{pH}$ (Table 2). Temperature affects the chemistry of metals by modifying their speciation, solubility, reaction rates and/or physical kinetics (Blust et al. 1994; Byrne et al. 1988). Higher temperatures increase TE bioavailability and consequently their bioaccumulation, as reported by RouaneHacene et al. (2015) in M. galloprovinciallis from Algerian coasts. Salinity also appeared to influence the accumulation of TE in A. noae flesh from Bizerte lagoon. Phillips (1976) observed a net decrease in $\mathrm{Pb}$ accumulation in Mytilus edulis in low salinity conditions. In contrast, both temperature and salinity do not influence the bioaccumulation of certain trace elements, as it was reported in this study for $\mathrm{Zn}$ in $A$. noae soft tissue. Phillips (1976) reported that the accumulation of $\mathrm{Zn}$ in M. edulis tissues was not affected by seawater temperature and salinity. It also seems that $\mathrm{pH}$ affects the accumulation of TE in A. noae soft tissue. According to Basraoui et al. (2010), $\mathrm{pH}$ has a major influence on the speciation of TE in water as the bioavailability of TE increases when the environment is alkaline, while it decreases for low $\mathrm{pH}$ values (Pelletier, 2006). In general, physical, chemical and biological mechanisms interact and transform environmental contaminants into more or less available forms (Gourlay 2004).In addition, several authors have linked the increase in TE concentrations in the tissues of invertebrate and fish species during summer to the increase of metabolism because of high temperature (Ali and Abdel-Satar 2005; Ibrahim and Omar 2013). George et al. (2013) further explained that a substantial increase in the precipitated form of metals in the water column coupled with high filtration rate during the warm season could explain the high metal levels in bivalve tissues. Kamel et al. (2014) and Kefi et al. (2015) have also reported higher accumulation of $\mathrm{Cd}, \mathrm{Cu}, \mathrm{Zn}$ and $\mathrm{Ni}$ in Mytilus galloprovincialis from the Bizerte lagoon and for $\mathrm{Pb}$ in Lithophaga lithophaga in the Bizerte Bay during summer. Seasonal fluctuations in TE concentrations may be related to environmental conditions but also temporal variability in the physiological status of organisms (Bordin et al. 1992). 
Fig. 2 Seasonal variations (mean $\pm \mathrm{SD} ; n=30$ ) of biomarker responses in the soft tissues of A. noae collected from Bizerte lagoon. a Malondialdehyde (MDA). b Glutathione peroxidase (GPx). c Reduced glutathione (GSH). d Metallothioneins (MTs). e Acetylcholinesterase (AChE). Letters indicate significant differences between seasons at $p<0.05$ a

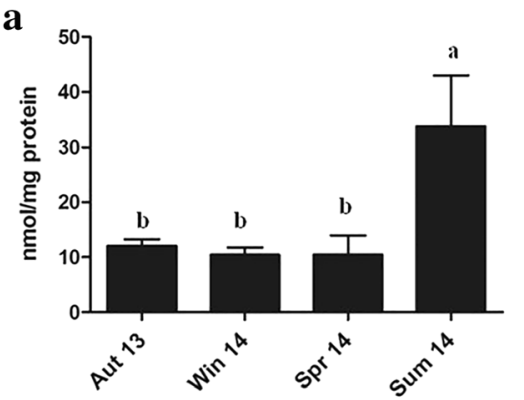

b

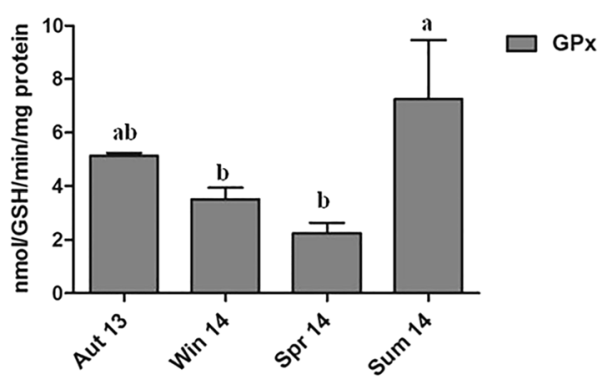

c

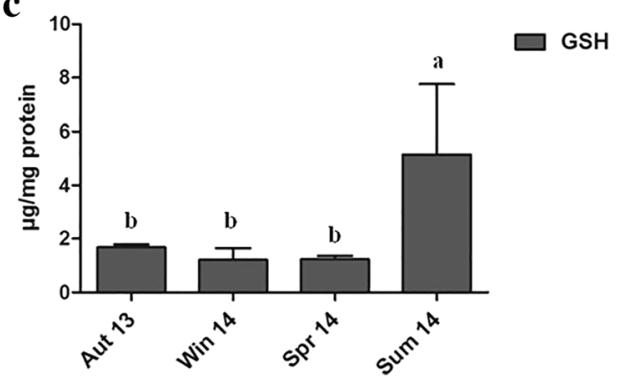

d

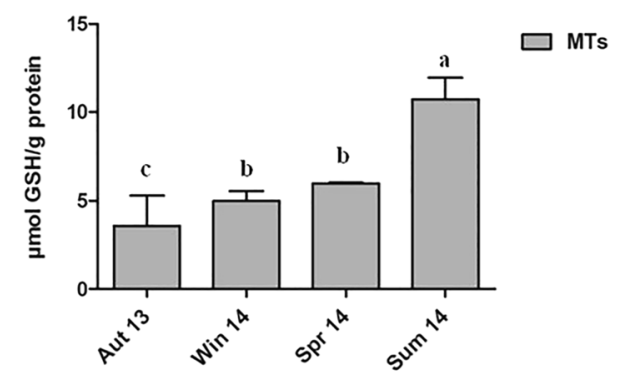

E.

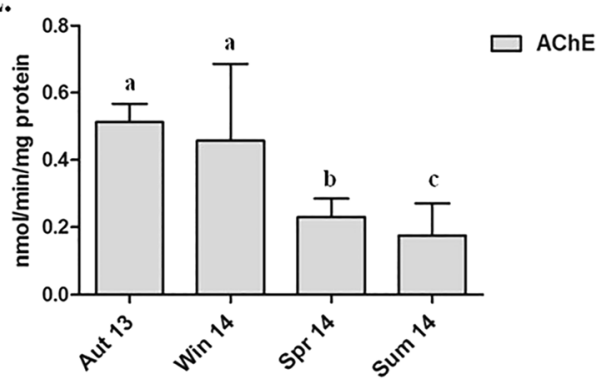

A. noae from the Bizerte lagoon shows a rather different pattern of reproduction when compared with $A$. noae populations from the Adriatic Sea. The reproductive cycle was characterized by two discrete maturing/spawning phases differing in terms of both length and intensity. The first one starts with a very rapid ovarian maturation phase in October to November, which is followed by a long, slow rate spawning phase extending from November to March. Afterward, a new ripening phase occurred from April to June/July, which is followed by a short massive spawning in late summer and early autumn (September) (Ghribi et al. 2017).

In our previous research, we reported that $A$. noae body dry weight (BDW) is relatively constant during the first reproductive phase (from October to March), while it increased significantly during the second phase from April to reach its maximum in July indicating a rapid increase in biomass caused by growth of gonadal and somatic tissues (see Ghribi et al. 2017). This increase coincided with high food uptake $(\mathrm{Chl} a)$ in the lagoon waters and important reserve materials accumulation (Ghribi et al. 2018). The use of the gonad index (GI), as a descriptor of the ecophysiological and health status of marine organisms, reflected in part the evolution of the sexual cycle of
A. noae in the Bizerte lagoon (Fig. S1). GI varied similarly to BDW confirming that gonadal mass mainly increased significantly during the second reproductive phase from early spring to reach its maximum in summer when gonads are fully ripe and gametes are ready to be released. Thereby, the high TE levels recorded in summer in A. noae soft tissue coincided with the significant increase in BDW and GI. GI was significantly positively correlated to five trace elements among all measured TE (Ni: $r=0.563$; Mn: $r=0.435 ; \mathrm{Cu}: r=0.685$; Se: $r=0.548$ and $\mathrm{Pb}: r=0.458 p<0.05$ ) (Table 2). Several studies have also reported higher TE concentrations in the flesh of several mollusk species during gonad maturation and lower ones during the spawning period (Cheggour et al., 1999; Idardare et al. 2011; Mubiana et al. 2005). Boussoufa et al. (2014) showed that the high bioaccumulation of $\mathrm{Pb}, \mathrm{Zn}$ and $\mathrm{Cu}$ in Donax truculus from the Gulf of Tunis coincided with the period of gametogenesis and gonad maturation. However, this increase in TE levels in bivalve body soft tissues before spawning (maturation phase) is not systematic for all species. Many authors have reported a decrease in TE concentrations during this phase in M. galloprovancialis and C. gigas (e.g. Amiard and Berthet 1996; Raspor et al., 2004; Richir and 
Table 4 Human risk assessment associated with the consumption of Arca noae harvested from the lagoon of Bizerte: trace element (TE), oral reference dose (RfD), provisional Tolerable Weekly Intake (PTWI), estimated weekly intake (EWI), target hazard quotient (THQ) and target cancer risk (TR)

\begin{tabular}{|c|c|c|c|c|c|c|c|c|c|c|c|c|c|c|}
\hline \multirow[t]{2}{*}{ TE } & \multirow[t]{2}{*}{$\mathrm{RfD}$} & \multirow[t]{2}{*}{ PTWI } & \multicolumn{4}{|l|}{ EWI } & \multicolumn{4}{|l|}{ THQ } & \multicolumn{4}{|l|}{$\mathrm{TR}$} \\
\hline & & & Autumn & Winter & Spring & Summer & Autumn & Winter & Spring & Summer & Autumn & Winter & Spring & Summer \\
\hline $\mathrm{Cd}$ & 0.001 & 420 & 0.37 & 0.49 & 0.51 & 0.58 & 0.052 & 0.071 & 0.072 & 0.083 & & & & \\
\hline $\mathrm{Cr}$ & 0.003 & 38,220 & 0.17 & 0.17 & 0.15 & 0.24 & 0.008 & 0.008 & 0.007 & 0.012 & & & & \\
\hline $\mathrm{Cu}$ & 0.04 & 210,000 & 2.71 & 2.43 & 3.23 & 4.09 & 0.010 & 0.009 & 0.012 & 0.015 & & & & \\
\hline $\mathrm{Fe}$ & 0.7 & 336,000 & 94.33 & 82.13 & 75.72 & 117.43 & 0.019 & 0.017 & 0.015 & 0.024 & & & & \\
\hline $\mathrm{Mn}$ & 0.14 & & & & & & 0.008 & 0.007 & 0.008 & 0.012 & & & & \\
\hline $\mathrm{Pb}$ & 0.00357 & 1500 & 0.62 & 0.31 & 0.73 & 1.17 & 0.022 & 0.011 & 0.026 & 0.042 & $7.558 \mathrm{E}-07$ & $3.82 \mathrm{E}-07$ & $8.805 \mathrm{E}-07$ & $1.426 \mathrm{E}-06$ \\
\hline $\mathrm{Se}$ & 0.005 & & & & & & 0.061 & 0.065 & 0.084 & 0.087 & & & & \\
\hline $\mathrm{Zn}$ & 0.3 & 420,000 & 96.25 & 107.80 & 108.44 & 112.93 & 0.046 & 0.051 & 0.052 & 0.054 & & & & \\
\hline \multicolumn{7}{|c|}{ Total THQ } & 0.226 & 0.239 & 0.276 & 0.329 & & & & \\
\hline
\end{tabular}

Gobert 2014). This decrease is known as biological dilution results from the dilution of TE, when the volume of gonads increases during the maturation phase of gametes. Subsequently, TE are concentrated during egg-laying when the gonad volume decreases following the release of the gametes.

Comparing our results with those reported for A. noae from the Croatian (Cuculic' et al. 2010, Ivankovic et al. 2016, Milun et al. 2016, Erk et al. 2018) and Yugoslav Adriatic coasts (Ozretic' et al. 1990), Zn, Cu, Ni, Cr, Pb, Cd, Fe, Mn, $\mathrm{Se}$ and $\mathrm{Al}$ concentrations were within the same range of concentrations (Table 5). Concentrations of these TE in A. noae flesh were similar to lower when compared with other bivalves from Bizerte lagoon, Tunisian and Mediterranean coasts (Kamel et al. 2014; Richir and Gobert 2014; Boussoufa et al. 2014; Joksimovic et al. 2018; Prato et al. 2019; Uluturhan et al. 2019) (Table 5).

As producers of reactive oxygen species (ROS), TE accumulation and environmental factors could contribute and generate severe biological responses, known as biomarkers, leading to irreversible damages in marine organisms (Nieto et al. 2010). Oxidative stress biomarkers in A. noae from Bizerte lagoon showed an important temporal variability. In this study, the higher and positive correlation of MDA level recorded during summer with $\mathrm{Cr}, \mathrm{Mn}, \mathrm{Cu}, \mathrm{Al}, \mathrm{Se}$ and $\mathrm{Pb}$ (Table 2) could be associated with the rise of environmental factors (T, S etc.) and TE concentrations in the lagoon waters. However, during winter, MDA decrease might be related to low temperatures and rainfall that contribute greatly to the dilution of TE of the water surface. According to Bouki et al. (2013) and Mahmoud et al. (2010) the highest levels of MDA were recorded in M. galloprovincialis and Fulvia fragilis, respectively, from the Bizerte lagoon as a response to environmental TE levels increase.

In the current study, significant and positive correlation of GSH levels was detected $(p<0.05)$ with $\mathrm{Fe}, \mathrm{Mn}, \mathrm{Cu}, \mathrm{Al}, \mathrm{Se}$ and $\mathrm{Pb}$ levels in $\mathrm{A}$. noae flesh from Bizerte lagoon (Table 2).
These results coincide with the findings of Mahmoud et al. (2010) carried on $F$. fragilis collected from Bizerte lagoon. Similarly, Bejaoui et al. (2017) reported high GSH levels in $V$. decussata digestive glands as a response to metal contamination in Boughrara lagoon (Tunisia). The seasonal variation of GPx activity was higher during summer and presents a positive correlation with $\mathrm{Pb}(p<0.05)$ (Table 2). This increase could be an adaptive response to eliminate the effect of hazardous ROS generated by environmental stressors (pollution, T and S) as reported by Carregosa et al. (2014) in three species of veneridae. Our results also corroborate with the findings of Orbea et al. (2002). These authors reported that oysters from the Biscay bay exhibited the highest GPx activity during summer than winter.

The inhibition of AChE activity was also evaluated in the soft tissues of $A$. noae revealing a significant decrease during the summer season when compared with the other seasons. Such results could be related to exposure to many other chemicals like TE, hydrocarbons and detergents (Elumalai et al. 2002). AChE is present in neuromuscular junctions and cholinergic synapses in the central nervous system and stops signal transmission by hydrolyzing acetylcholine (Ach), a neurotransmitter that drives nerve impulses through neuromuscular junctions (Bocquené et al., 1997; Lodish et al. 2000). AChE inhibition has been used for years as a marker of exposure to aquatic contaminants (mainly insecticides) (Bocquené et al., 1997). In our study, the significant $(p<0.05)$ decrease of AChE activity in A. noae harvested during summer was negatively correlated with all TE concentrations except $\mathrm{Zn}$ and $\mathrm{Cd}$ (Table 2). Similarly, previous reports of Dellali et al. (2001), Barhoumi et al. (2014) and Kamel et al. (2014) have described the decrease of AChE activity in oysters and mussels collected from Bizerte lagoon from the most affected region by agricultural activities and industrial releases. 
Besides, MTs levels in A. noae flesh collected from Bizerte lagoon varied between seasons and reached high concentrations in summer. This increase was positively correlated $(p<0.05)$ with all TE except Zn (Table 2). Due to the biological reactivity of metallothionein (MT) in response to the bioaccumulation of metals, it has been suggested that these low molecular weight proteins are suitable molecular indicators of metal pollution (Roesijadi, 1994). These metal-binding proteins are believed to participate in the functions associated with the metabolism and detoxification of metals (Marie et al. 2006). MTs roles comprise: (i) the homeostatic regulation of essential metals, such as $\mathrm{Zn}$ or $\mathrm{Cu}$; (ii) detoxification via the chelation of harmful TE ( $\mathrm{Cd}$ or $\mathrm{Hg}$ ); and (iii) the protection of tissues against various forms of oxidative injury (Marie et al. 2006). With regard to seasonal variations, our results are consistent with the findings of De Clercq (2016), Kamel et al. (2014) and Leinio and Lehtonen (2005). These authors reported high MTs levels during summer in A. noae from the Adriatic Sea, in M. edulis from the Baltic Sea and in M. galloprovancialis from Bizerte Lagoon, respectively. Moreover, Geffard et al. (2002) and Chandurvelan et al. (2015) showed that high levels of MTs measured in situ and under laboratory-controlled conditions in oyster and mussel tissues following metals exposure.

To sum up, the high biomarker responses during summer appear to be mainly related to the accumulation of TE in A. noae flesh that inducing oxidative stress in organisms leading to physiological disturbances and antioxidants activation (Verlecar et al. 2007; Bejaoui et al. 2018). In addition, high biomarker responses during the summer period may also be related to seasonal changes in environmental parameters (high temperature, low oxygen levels etc.), as reported by Cravo et al. (2012) for $R$. decussatus in a low contaminated lagoon
(Ria Farmosa, Portugal). In this regard, the temperature seems to be also a determinant factor inducing biomarker responses in A. noae from Bizerte lagoon. The temperature was positively correlated with MDA, GSH, MTs levels and GPx activity, while it was negatively correlated with AChE activity (Table 2). The effect of temperature on biomarker responses and enzymatic activities has already been reported by other authors in different bivalve species (Barhoumi et al. 2014; Dellali et al. 2001). It has also been suggested that salinity fluctuation may influence the ability of bivalves to face oxidative stress (Prevodnik et al. 2007). It can be concluded that relationships between various biomarker responses are an adaptive response of $A$. noae to counteract the adverse effects of ROS caused by TE bioaccumulation but also stressful environmental conditions as discussed below.

From a nutritional point of view, TE concentrations on a wet weight basis in A. noae from the lagoon of Bizerte were well below international food safety standards and the maximum allowable level in bivalve flesh set by the international organizations Food and Agriculture Organization of the United Nations (FAO, 1983), European Community (EC 2006) and US Food and Drug Administration (USFDA 2001). EWI values for $A$. noae at the four different seasons were far below the PTWI values. Therefore, the consumption of this bivalve does not pose sanitary problems. EWI values are in agreement with values given in previous studies for bivalves (Storelli and Marcotrigiano 2001; Yusa et al. 2008) and fishes (Marengo et al. 2018; Turkmen et al. 2010). THQ is a useful parameter to assess the risk associated with the intake of TE contaminated shellfish (Storelli 2008) and fishes (Copat et al. 2013). The acceptable guideline value for THQ is 1 (USEPA 2010). THQ values were less than 1 for A. noae analyzed in this study, indicating no potential carcinogenic
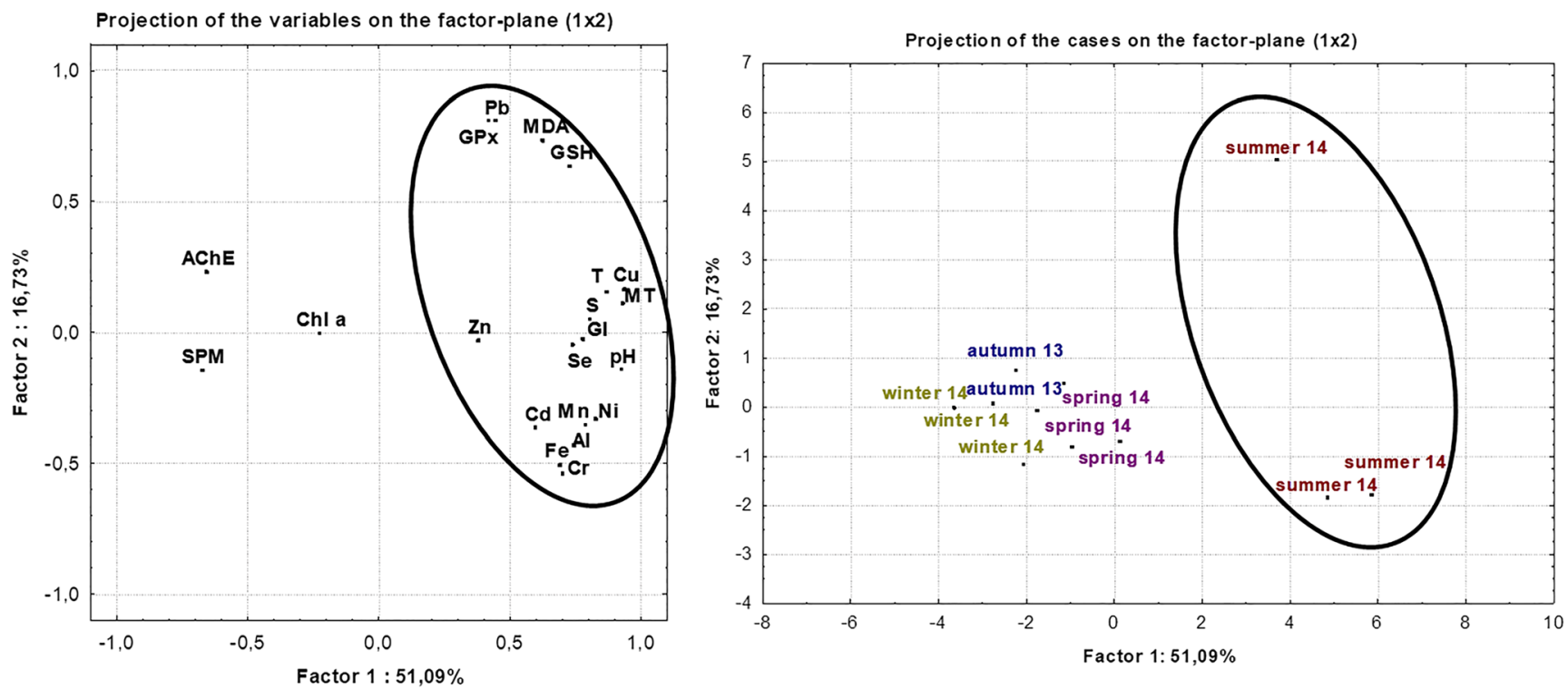

Fig. 3 Principal component analysis (PCA) of the examined TE, biomarker responses, body dry weight (BDW) and environmental parameters. (a) 2D factor loadings plot and (b) 2D scores plot in the space defined by the two first factorial axes of the PCA 
Table 5 Comparison of TE concentrations (in $\mathrm{mg} / \mathrm{kg}$ of dry weight (DW) or wet weight (WW)) in A. noae from Bizerte lagoon and the Adriatic Sea with other bivalves from different Mediterranean coastal areas. Concentrations are also compared with maximum levels of TE admissible in shellfish flesh, as set by the FAO, the EC and the USFDA

\begin{tabular}{|c|c|c|c|c|c|c|c|}
\hline & Species & Location & Reference & $\mathrm{Ni}$ & $\mathrm{Fe}^{*}$ & $\mathrm{Cr}$ & $\mathrm{Mn}^{*}$ \\
\hline 1. & $\begin{array}{l}\text { Arca noae }(D W) \\
\text { Arca noae }(W W)\end{array}$ & Bizerte lagoon (Tunisia) & Present study & $\begin{array}{l}0.21-0.96 \\
0.05-0.24\end{array}$ & $\begin{array}{l}71.4-317 \\
17.58-79.25\end{array}$ & $\begin{array}{l}0.10-0.62 \\
0.02-0.15\end{array}$ & $\begin{array}{l}4.61-32.49 \\
1.15-8.12\end{array}$ \\
\hline 2. & A. noae (DW) & Adriatic Sea (Croatia) & Erk et al. (2018) & $0.44-1.01$ & $151-438$ & $0.66-1.60$ & $6.93-16.76$ \\
\hline 3. & A. noae (DW) & Adriatic Sea (Croatia) & Ivankovic et al. (2016) & $0.45-1.14$ & & $0.47-1.70$ & \\
\hline 4. & A. noae (DW) & Adriatic Sea (Croatia) & Milun et al. (2016) & $0.95-4.64$ & & $0.87-3.43$ & \\
\hline 5. & A. noae (DW) & Adriatic Sea (Croatia) & Cuculic et al. (2010) & & & & \\
\hline 6. & A. noae (DW) & Adriatic Sea (Croatia) & Ozretic et al. (1990) & & & & \\
\hline 7. & Mytilus galloprovancialis (DW) & Bizerte lagoon (Tunisia) & Kamel et al. (2014) & $1.68-4.16$ & & & \\
\hline 8. & Donax trunculus (DW) & Gulf of Tunis (Tunisia) & Boussoufa et al. (2014) & & & $1.2-6$ & $7-70$ \\
\hline 9. & Modiolus barbatus (WW) & Italian coast & Prato et al. (2019) & $1.06-1.14$ & & $1.41-1.61$ & \\
\hline 10. & Tapes decussatus (DW) & Turkish coast & Uluturhan et al. (2019) & & $257-1083$ & $2.90-17.0$ & $8.70-21.6$ \\
\hline 11. & M. galloprovancialis (DW) & Montenegrin coast & Joksimovic et al. (2018) & & & $0.72-4.05$ & \\
\hline 12. & M. galloprovancialis (DW) & Diane Pond (Eastern Corsica) & Richir and Gobert (2014) & $0.71-3.39$ & $66-656$ & $0.19-2.17$ & $3.4-20.6$ \\
\hline 13. & M. galloprovancialis (DW) & French Mediterranean coasts & RINBIO (2001) & 2 & & 1 & \\
\hline 14. & Bivalves (WW) & & FAO (2003) & & & & \\
\hline 15. & Bivalves (WW) & & EC (2006) & & & & \\
\hline 16. & Bivalves (WW) & & USFDA (2001) & 80 & & 13 & \\
\hline & $\mathrm{Cu}$ & $\mathrm{Zn}$ & $\mathrm{Cd}$ & $\mathrm{Al}^{*}$ & $\mathrm{Se}^{*}$ & $\mathrm{~Pb}$ & \\
\hline 1. & $\begin{array}{l}2.03-8.70 \\
0.50-2.17\end{array}$ & $\begin{array}{l}82.2-269 \\
20.55-69.75\end{array}$ & $\begin{array}{l}0.27-1.66 \\
0.06-0.41\end{array}$ & $\begin{array}{l}9.51-214.37 \\
2.37-53.5\end{array}$ & $\begin{array}{l}2.02-5.99 \\
0.50-1.49\end{array}$ & $\begin{array}{l}0.28-4.45 \\
0.07-1.11\end{array}$ & \\
\hline 2. & $3.08-6.26$ & $77-179$ & $0.89-3.47$ & $47-179$ & $4.50-9.79$ & $0.38-0.82$ & \\
\hline 3. & $3.08-6.82$ & $100-358$ & $0.68-3.67$ & & & $0.31-1.20$ & \\
\hline 4. & $3.69-202.3$ & $55.76-4010.3$ & $0.23-4.03$ & & & $0.95-4.64$ & \\
\hline 5. & $2.85-13.23$ & $89.7-167.6$ & $1.52-2.84$ & & & $0.59-0.69$ & \\
\hline 6. & & & 3.35 & & & 0.55 & \\
\hline 7. & $1.72-3.70$ & $22.84-43.17$ & $0.18-0.49$ & & & & \\
\hline 8. & $5.8-15.3$ & $68.3-87.5$ & $0.1-0.66$ & & & $3.3-5.3$ & \\
\hline 9. & & & $0.63-0.68$ & & & $0.65-0.75$ & \\
\hline 10. & $4.06-7.09$ & $43.6-51.3$ & $0.07-0.32$ & & & $0.27-1.57$ & \\
\hline 11. & $6.08-13.2$ & $85.6-241$ & $1.01-2.87$ & & & $1.37-3.55$ & \\
\hline 12. & $2.8-7.4$ & $35-224$ & $0.21-1.03$ & $39-877$ & $1.5-4.3$ & $0.14-1.10$ & \\
\hline 13. & $2.9-9.2$ & 116-203 & $0.1-5.9$ & & & $0.5-5.4$ & \\
\hline 14. & $10-30$ & $40-100$ & 2 & & & $1-6$ & \\
\hline 15. & & & 1 & & & 1.5 & \\
\hline 16. & & & 4 & & & 1.7 & \\
\hline
\end{tabular}

FAO Food and Agriculture Organization of the United Nations, EC European Communities, USFDA United States Food and Drug Administration *No security limits defined for this element

risk from ingestion of a single TE through their consumption. Consumption of $A$. noae involved exposure to a mixture of TE. Values of cumulative health risks (TTHQ, the sum of health risks of the $10 \mathrm{TE}$ ) were however also less than 1, again indicating no potential significant health risk from TE ingestion. The risk of cancer due to exposure to $\mathrm{Pb}$ was not of concern since the values of TR were lower than the acceptable risk limit of $10^{-4}$ (USEPA 2010). From all these observations, it can be said that continued consumption over long periods of this shellfish may not represent a potential risk to the health of consumers regarding $\mathrm{Zn}, \mathrm{Fe}, \mathrm{Al}, \mathrm{Mn}, \mathrm{Cu}, \mathrm{Se}, \mathrm{Pb}, \mathrm{Cd}, \mathrm{Ni}$ and Cr. Our results for THQ, TTHQ and TR correspond to previous studies on fishes (Saha et al. 2016; Marengo et al. 2018; Vieira et al. 2011). In addition, we can estimate that the (sub) population of $A$. noae inhabiting the south part of Bizerte lagoon is potentially a safe food regarding TE and can be recommended for possible commercialization and human consumption in Tunisia. However, prior to that, the 
investigation of $A$. noae potential contamination by other toxic compounds (OCPs, PCBs, HAPs etc.) is strongly recommended. If safety is observed for other chemicals as for TE, farming and exploitation of this species in Bizerte lagoon can be developed, after applying sanitary measures required to set out the basic rules for food safety and animal health standards.

\section{Conclusions}

The present study highlighted the seasonal accumulation of TE and environmental conditions on the metabolic responses of A. noae, in relationship with its reproductive cycle that was presented by the gonad index (GI). The battery of parameters applied in the present work including A. noae oxidative response (MDA, GPx, GSH, MTs and AChE) and TE accumulation provides a discrimination of seasons with different levels of contamination, especially during summer season. Regarding health risk assessment linked to $A$. noae consumption, all sanitary indicators (EWI, PTWI, THQ, TTHQ and TR) related to TE levels bioaccumulation were below the risk for human health standards. Consequently, A. noae can be considered as a safe shellfish product for human consumption in Tunisia, based on its beneficial properties for health and nutritional quality, so Tunisians are encouraged to consume this shellfish. This work is the first step towards the valorization of this unexploited shellfish species in Tunisia since this bivalve being already commercialized and consumed in other areas from the Mediterranean (Adriatic Sea). As perspectives for this study, other investigations must be determined using A. noae collected from other area. Additionally, studies on the TE levels in the sediment and waters are mandatory in order to present a total examination of the study area. Finally, we plan to confirm the correlations between field effects and measure exposure concentrations by controlled laboratory experiments."

Acknowledgments Authors are grateful to Mr. Renzo Biondo (University of Liege, Belgium) who performed ICP-MS analysis and for his technical assistance. The authors wish to thank anonymous referees for useful comments and critical reading of the manuscript.

\section{Compliance with ethical standards}

Conflict of interest The authors declare that they have no conflict of interest.

\section{References}

Adamo P, Arienzo M, Imperato M, Naimo D, Nardi G, Stanziones D (2005) Distribution and partition of heavy metals in surface and sub-surface sediments of Naples city port. Chemosphere 61:800 809
Ali M, Abdel-Satar A (2005) Studies of some heavy metals in water, sediment, fish and fish diets in some fish farms in El-Fayoum province. Egypt J Aquat Res 31:261-273

Ali Z, Malik RN, Qadir A (2013) Heavy metals distribution and risk assessment in soils affected by tannery effluents. Chem Ecol 29: 676-692. https://doi.org/10.1080/02757540.2013.810728

Amiard JC, Pineau A, Boiteau HL, Metayer C, Amiard-Triquet C (1987) Application de la spectrométrie d'absorption atomique Zeeman aux dosages de huit éléments traces $(\mathrm{Ag}, \mathrm{Cd}, \mathrm{Cr}, \mathrm{Cu}, \mathrm{Mn}, \mathrm{Ni}, \mathrm{Pb}$ et $\mathrm{Se}$ ) dans des matrices biologiques solides. Water Res 21:693-697. https://doi.org/10.1016/0043-1354(87)90081-9

Amiard JC, Berthet B (1996) Fluctuations of cadmium, copper, lead and zinc concentrations in field populations of the Pacific oyster Crassostrea gigas in the bay of Bourgneuf (France). Ann Inst Oceanogr 72:195-207

Aminot A, Chaussepied C (1983) Manuel des Analyses Chimiques en Milieu Marin. Centre National d'Exploitation des Océans, Brest

Barhoumi B, Le Menach K, Clérandeau C, Ameur WB, Budzinski H, Driss MR, Cachot J (2014) Assessment of pollution in the Bizerte lagoon (Tunisia) by the combined use of chemical and biochemical markers in mussels, Mytilus galloprovincialis. Mar Pollut Bull 84: 379-390. https://doi.org/10.1016/j.marpolbul.2014.05.002

Barhoumi B (2014) Biosurveillance de la pollution de la lagune de Bizerte (Tunisie) par l'analyse comparée des niveaux de contamination et de l'écotoxicité des sédiments et du biote. Université de Bordeaux, Thèse de doctorat, 245p

Basraoui Y, Zegmout M, Eladdouli J, Demnati S, Chahlaoui A (2010) Contribution à l'étude de la pollution de la zone côtière Saidia/ Moulouya (Maroc Nord Oriental). Afrique Sci 6:64-74 http:// www. afriquescience.info/document.php?id=2044

Béjaoui B, Harzallah A, Moussa M, Chapelle A (2008) Modèle couplé dynamique-écologie pour la lagune de Bizerte. BullInst Nat Sci Tech Mer Salammbô 35:31-148

Béjaoui B, Solidoro C, Harzallah A, Chevalier C, Chapelle A, Zaaboub $\mathrm{N}$, Aleya L (2017) 3D modeling of phytoplankton seasonal variation and nutrient budget in a southern Mediterranean lagoon. Mar Pollut Bull 114:962-976. https://doi.org/10.1016/j.marpolbul.2016.11.001

Bejaoui S, Boussoufa D, Tir M, Haouas-Gharsallah I, Boudawara T, Ghram A, El Cafsi M, Soudani N (2017) DNA damage and oxidative stress in digestive gland of Venerupis decussata collected from two contrasting habitats in the southern Tunisian coast: biochemical and histopathological studies. Cah Biol Mar 58:123-135. https:// doi.org/10.21411/CBM.A.133C71C1

Bejaoui S, Telahigue K, Chetoui I, Rabeh I, Fouzai C, Trabelsi W, HouasGharsallah I, El Cafsi M, Soudani N (2018) Integrated effect of metal accumulation, oxidative stress responses and DNA damage in Venerupis decussata gills collected from two coast Tunisian lagoons. J Chem Environm biol Eng 2:44-51. https://doi.org/10. 11648/j.jcebe. 20180202.12

Ben Garali A, Ouakad M, Gueddari M (2009) Bilans hydrologiques de la lagune de Bizerte nord-est de la Tunisie. J Water Sci 22:525-534. https://doi.org/10.7202/038329ar

Blust R, Ginneken LV, Decleir W (1994) Effect of temperature on the uptake of copper by the brine shrimp, Artemia fransiscana. Aquat Toxicol 30:343-356. https://doi.org/10.1016/0166-445X(94)00049-2

Bordin G, McCourt J, Rodriguez A (1992) Trace metals in the marine bivalve Macoma balthica in the Westerschelde estuary, the Netherland. Part 1: analysis of total copper, cadmium, zinc and iron- locational and seasonal variations. Sci Total Environ 127: 225-280. https://doi.org/10.1016/0048-9697(92)90507-O

Bocchetti R, Regoli F (2006) Seasonal variability of oxidative biomarkers, lysosomal parameters, metallothioneins and peroxisomal enzymes in the Mediterranean mussel Mytilus galloprovincialis from Adriatic Sea. Chemosphere 65:913-921. https://doi.org/10. 1016/j.chemosphere.2006.03.049 
Bocquené G, Roig A, Fournier D (1997) Cholinesterases from the common oyster (Crassostrea gigas) evidence for the presence of a soluble acetylcholmesterase insensitive to organophosphate and carbamate inhibitors. FEBS Lett 407:261-266

Bouki E, Dimitriadis VK, Kaloyianni M, Dailianis S (2013) Antioxidant and pro-oxidant challenge of tannic acid in mussel hemocytes exposed to cadmium. Mar Environ Res 85:13-20. https://doi.org/10. 1016/j.marenvres.2012.12.005

Boussoufa D, Ghazali N, Masmoudi W, El Cafsi M (2014) Biomonitoring of trace metal pollution using the mollusc bivalve Donax Trunculus and the surface sediment from the Mediterranean coast of northern Tunisia. Int J Engin Sci Res Tech 3:355-375

Brik B, Aydi A, Riahi C, Sdiri A, Regaya K (2018) Contamination levels and vertical distribution of trace metals with application of geochemical indices in the sediment cores of the Bizerte LagoonIchkeul lake complex in northeastern Tunisia. Arab J Geosci 11: 23-15. https://doi.org/10.1007/s12517-017-3382-5

Byrne RH, Kump LR, Cantrell KJ (1988) The influence of temperature and $\mathrm{pH}$ on trace metal speciation in seawater. Mar Chem 25:168 181. https://doi.org/10.1016/0304-4203(88)90062-X

Carregosa V, Velez C, Soares AM, Figueira E, Freitas R (2014) Physiological and biochemical responses of three Veneridae clams exposed to salinity changes. Comp Biochem Physiol B Biochem Mol Biol 178:1-9. https://doi.org/10.1016/j.cbpb.2014.08.001

Chamannejadian A, Sayyad G, Moezzi A, Jahangiri A (2013) Evaluation of estimated daily intake (EDI) of cadmium and lead for rice (Oryza sativa L.) in calcareous soils. Iran J environ health Sci Eng 10:1. https://doi.org/10.1186/1735-2746-10-28

Chandurvelan R, Marsden I, Glover C, Gaw S (2015) Assessment of a mussel as a metal bioindicator of coastal contamination: relationships between metal bioaccumulation and multiple biomarker responses. Sci Total Environ 511:663-675. https://doi.org/10.1016/j. scitotenv.2014.12.064

Cheggour M, Chafik A, Texier H, Bouhallaoui A, Gharbi N, Boumezzough A, Elattar J (1999) Bioaccumulation de quelques éléments métalliques chez l'huître Crassostrea gigas en élevage dans la lagune de Oualidia (Maroc) : Rôle des facteurs écologiques et biologiques. Haliotis 28:31-44

Chen CW, Kao CM, Chen CF, Dong CD (2007) Distribution and accumulation of heavy metals in the sediments of Kaohsiung Harbor, Taiwan. Chemosphere 66:1431-1440

Chien LC, Hung TC, Choang KY, Yeh CY, Meng PJ, Shieh MJ, Han BC (2002) Daily intake of TBT, Cu, Zn, Cd and As for fishermen in Taiwan. Sci Total Environ 285:177-185

Chiffoleau JF, Claisse D, Cossa D, Ficht A, Gonzalez JL, Guyot T, Michel P, Miramand P, Oger C, Petit F (2001) La contamination métallique. Ifremer, Editions, 39p

Copat C, Arena G, Fiore M, Ledda C, Fallico R, Sciacca S, Ferrante M (2013) Heavy metals concentrations in fish and shellfish from eastern Mediterranean Sea: consumption advisories. Food Chem Toxicol 53:33-37. https://doi.org/10.1016/j.fct.2012.11.038

Cravo A, Pereira C, Gomes T, Cardoso C, Serafim A, Almeida C, Rocha T, Lopes B, Company R, Medeiros A, Norberto R, Pereira R, Araújo O, Bebianno MJ (2012) A multibiomarker approach in the clam Ruditapes decussatus to assess the impact of pollution in the Ria Formosa lagoon, south coast of Portugal. Mar Environ Res 75:23 34. https://doi.org/10.1016/j.marenvres.2011.09.012

Cuculic VV, Cukrov N, Kwokal Z, Mlakar M (2010) Trace metals in bivalves' soft tissue from Mljet National Park Aquatorium, Croatia. Rapp 39 Congr Comm Int Explor Sci Mediterr 39:237

Currie L (1999) Nomenclature in evaluation of analytical methods including detection and quantification capabilities (IUPAC recommendations 1995). Anal Chim Acta 391:105-126

D'Adamo R, Di Stasio M, Fabbrochini A (2008) Migratory crustaceans as biomonitors of metal pollution in their nursery areas.The Lesina lagoon (SE Italy) as a case study. Eviron Monit Assess 143:15-24. https://doi.org/10.1007/s10661-007-9944-3

De Clercq N (2016) Seasonal variations in biochemical composition and metallothionein contents of digestive gland of Noah's ark shell (Arca noae Linnaeus, 1758) from the Adriatic Sea., diplomski rad, preddiplomski, faculty education, health and social work, master degree, University of Ghent, 77p

Dellali M, Gnassia Barelli M, Romeo M, Aissa P, (2001) The use of acetylcholinesterase activity in Ruditapes decussatus and Mytilus galloprovincialis in the biomonitoring of Bizerta lagoon. Comparative Biochemistry and Physiology Part C: Toxicology \& Pharmacology 130 (2):227-235

Draper HH, Hadley M (1990) Malondialdehyde determination as index of lipid peroxidation. Methods Enzymol 186:421-431

EC (2006) Regulation (EC) No. 1881/2006 of the European Parliament and the Council of 19 December 2006 setting maximum levels for certain contaminants in foodstuffs. Official Journal of the European Communities L364/5-22

Edokpayi JN, Odiyo JO, Popoola OE, Msagati TAM (2016) Assessment of trace metals contamination of surface water and sediment: a case study of Mvudi River, South Africa. Sustainability8:1-13.https://doi. org/10.3390/su8020135

Ellman GL (1959) Tissue sulfhydryl groups. Arch Biochem Biophys 82: 70-77

Ellman GL, Courtney KD, Anders V, Featherstone RM (1961) A new and rapid colorimetric determination of acetylcholinesterase activity. Biochem Pharmacol 7:88-95. https://doi.org/10.1016/00062952(61)90145-9

Elumalai M, Antunes C, Guilhermino L (2002) Single metals and their mixtures on selected enzymes of Carcinus maenas. Water Air Soil Pollut 141:273-280. https://doi.org/10.1023/A:1021352212089

Erk M, Ivanković D, Župan I, Čulin J, Draguna Z, Puljas S, Peharda M (2018) Changes in the tissue concentrations of trace elements during the reproductive cycle of Noah's ark shells (Arca noae Linnaeus, 1758). Mar Pollut Bull 133:357-366. https://doi.org/10.1016/j. marpolbul.2018.05.054

FAO (1983) Compilation of legal limits for hazardous substances in fish and fishery products. FAO fishery circular no 464:5-100

FAO/WHO (2011) Evaluation of Certain Food Additives and Contaminants: Seventy-third [73rd] Report of the Joint FA

Flohe L, Günzler WA (1984) Assay of glutathione peroxidase. Methods Enzymol 105:115-121

Frías-Espericueta MG, Osuna-López JI, Sandoval-Salazar G, LópezLópez G (1999) Distribution of trace metals in different tissues in the rock oyster Crassostrea iridescens: seasonal variation. Bull Environ Contam Toxicol 63:73-79

Geffard A, Amiard JC, Amiard-Triquet C (2002) Use of metallothionein in gills from oysters (Crassostrea gigas) as a biomarker: seasonal and intersite fluctuations. Biomarkers 7:123-137. https://doi.org/10. 1080/13547500110091292

George RG, Martin D, Nair SM, Chandramohanakumar N (2013) Biomonitoring of trace metal pollution using the bivalve molluscs, Villorita cyprinoides, from the Cochin backwaters. Environ Monit Assess 185:10317-10331. https://doi.org/10.1007/s10661-013-3334-9

Ghribi F, Bello G, Zupa R, Passantino L, Santamaria N, El Cafsi M, Corriero A (2017) Reproductive and tissue plasticity in Arca noae (Bivalvia: Arcidae). European Zool J84:473-478. https://doi.org/10. 1080/24750263.2017.1368725

Ghribi F, Boussoufa D, Aouini F, Bejaoui S, Chetoui I, Rabeh I, El Cafsi M (2018) Seasonal variation of biochemical composition of Noah's ark shells (Arca noae L. 1758) in a Tunisian coastal lagoon in relation to its reproductive cycle and environmental conditions. Aquatic. Living. Res. 31: 14. https://doi.org/10.1051/alr/2018002

Gofas S (2008) Arca noae. In: Mollusca Base 2016. Accessed through: world register of marine species at http://www.marinespecies.org/ aphia.php? $\mathrm{p}=$ taxdetails\&id=138788 [accessed on 10.8.2016] 
Goldberg ED (1975) The mussel watch - a first step in a global marine monitoring. Mar Pollut Bull 6:111-114

Gourlay C (2004) Biodisponibilité des hydrocarbures aromatiques polycycliques dans les écosystèmes aquatiques: influence de la matière organique naturelle et anthropique. PhD Thesis. Ecole Nationale du Génie Rural, des Eaux et des Forêts

Grinzaid EL, Zil'bershtein KI, Nadezhina LS, Yufa BY (1977) Terms and methods of estimating detection limits in various analytical methods. J Analytic Chem USSR 32:1678-1684

Hrs-Brenko M, Legac M (1996) A review of bivalve species in the eastern Adriatic Sea: II. Pteriomorphia (Arcidae and Noetidae). Nat Croat 5:221-247

Ibrahim ATHA, Omar HM (2013) Seasonal variation of heavy metals accumulation in muscles of the African catfish Clarias gariepinus and in River Nile water and sediments at Assiut governorate, Egypt. J Biol Earth Sci 3:B236-B248

Idardare Z, Moukrim A, Chiffoleau JF, Ait Alla A (2011) Trace metals in the clam Donax trunculus L. from the Bouadisse sandy beach, discharge zone of a plant sewage outfall in Agadir Bay (Morocco). Bayed A. (ed.). Sandy beaches and coastal zone management Proceedings of the Fifth International Symposium on Sandy Beaches, 19th-23rd October 2009, Rabat, Morocco Travaux de l'Institut Scientifique, Rabat, série générale, $\mathrm{N}^{\circ} 6,51-58$

IUPAC, Inczédy J, Lengyel T, Ure AM, Gelencsér A, Hulanicki A (1998) Compendium of analytical nomenclature, 3rd edn. Blackwell, Oxford

Ivankovic D, Erk M, Zupan I, Culin J, Dragun Z, Bacic N, Cindric AM (2016) Trace metals in Noah's ark shells (Arca noae Linnaeus, 1758): impact of tourist season and human health risk. Arch Environ Contam Toxicol 71:394-404. https://doi.org/10.1007/ s00244-016-0298-0

Joksimović D, Castelli A, Perošević A, Djurović D, Stanković S (2018) Determination of trace metals in Mytilus galloprovincialis along the Boka Kotorska Bay. Montenegrin coast J Trace Elements Med Biol 50:601-608

Jović M, Stanković S (2014) Human exposure to trace metals and possible public health risks via consumption of mussels Mytilus galloprovincialis from the Adriatic coastal area. Food Chem Toxicol 70:241-251. https://doi.org/10.1016/j.fct.2014.05.012

Kamel N, Burgeot T, Banni M, Chalghaf M, Devin S, Minier C, Boussetta $\mathrm{H}$ (2014) Effects of increasing temperatures on biomarker responses and accumulation of hazardous substances in rope mussels (Mytilus galloprovincialis) from Bizerte lagoon. Environ Sci Pollut Res 21:6108-6123. https://doi.org/10.1007/s11356-0142540-5

Kefi FJ, Mleiki A, Maâtoug-Béjaoui J, Trigui-El Menif N (2015) Seasonal variations of trace metal concentrations in the soft tissue of Lithophaga Lithophaga collected from the Bizerte Bay (northern Tunisia, Mediterranean Sea). J Aquac Res Dev 7:432. https://doi. org/10.4172/2155-9546.1000432

Leiniö S, Lehtonen KK (2005) Seasonal variability in biomarkers in the bivalves Mytilus edulis and Macoma balthica from the northern Baltic Sea. Comp Biochem Physiol C 140:408-421. https://doi. org/10.1016/j.cca.2005.04.005

Lodish H, Berk A, Zipursky SL et al. (2000) Molecular Cell Biology.4th edition. New York: W. H. freeman

Lowry OH, Rosebrough NJ, Farr AL, Randal RJ (1951) Protein measurement with the folin phenol reagent. J Biol Chem 193:265-275

Mahmoud N, Dellali M, El Bour M, Aissa P, Mahmoudi E (2010) The use of Fulvia fragilis (Mollusca: Cardiidae) in the biomonitoring of Bizerta lagoon: a mutimarkers approach. Ecol Indic 10:696-702. https://doi.org/10.1016/j.ecolind.2009.11.010

Marengo M, Durieux EDH, Ternengo S, Lejeune P, Degrange E, Pasqualini V, Gobert S (2018) Comparison of elemental composition in two wild and cultured marine fish and potential risks to human health. Ecotoxicol Environ Saf 30(158):204-212. https:// doi.org/10.1016/j.ecoenv.2018.04.034

Marie V, Baudrimont M, Boudou A (2006) Cadmium and zinc bioaccumulation and metallothionein response in two freshwater bivalves (Corbicula fluminea and Dreissena polymorpha) transplanted along a polymetallic gradient. Chemosphere 65:609-617

Milun V, Lušić J, Despalatović M (2016) Polychlorinated biphenyls, organochlorine pesticides and trace metals in cultured and harvested bivalves from the eastern Adriatic coast (Croatia). Chemosphere 153:18-27. https://doi.org/10.1016/j.chemosphere.2016.03.039

Mubiana VK, Qadah D, Meys J, Blust R (2005) Temporal and spatial trends in heavy metal concentrations in the marine mussel Mytilus edulis from the Western Scheldt estuary (the Netherlands). Hydrobiologia 540:169-180 https://doi.org/10.1007/s10750-004-7134-7

Nadal M, Ferre-Huguet N, Marti-Cid R, Schuhmacher M, Domingo JL (2008) Exposure to metals through the consumption of fish and seafood by the population living near the Ebro River in Catalonia, Spain: health risks. Hum Ecol Risk Assess 14:780-795. https://doi. org/10.1080/10807030802235235

Nieto R, Garcia-Barrera T, Gomez-Ariza JL, Lopez Barea J (2010) Environmental monitoring of Domingo Rubio stream (Huelva estuary, SW Spain) by combining conventional biomarkers and proteomic analysis in Carcinus maenas. Environ Pollut 158:401-408. https://doi.org/10.1016/j.envpol.2009.09.005

ODEQ (2007) Guidance for assessing bioaccumulative Chemicals of Concern in sediment. Oregon Department of Environmental Quality. Environmental cleanup program: 07-LQ-023A

Olesik J, Jones D (2006) Strategies to develop methods using ionmolecule reactions in a quadrupole reaction cell to overcome spectral overlaps in inductively coupled plasma mass spectrometry. J Anal Atomic Spectro 21:141-159

Orbea A, Ortiz-Zarragoitia M, Sole M, Porte C, Cajaraville MP (2002) Antioxidant enzymes and peroxisome proliferation in relation to contaminant body burdens of PAHs and PCBs in bivalve molluscs, crabs and fish from the Urdaibai and Plentzia estuaries (Bay of Biscay). Aquat Toxicol 58:75-98

Ozretic B, Krajnovic-Ozretic M, Santin J, Medjugorac B, Kras M (1990) $\mathrm{As}, \mathrm{Cd}, \mathrm{Pb}$ and $\mathrm{Hg}$ in benthic animals from the Kvarner-Rijeka Bay region, Yugoslavia. Mar Pollut Bull 21:595-597. https://doi.org/10. 1016/0025-326X(90)90610-K

Pelletier E (2006) Seasonal variations of physiological parameters in the blue mussel Mytilus spp. from farm sites of eastern Quebec. Aquaculture 261:729-751. https://doi.org/10.1016/j.aquaculture. 2006.08.017

Perić L, Ribarić L, Nerlović V (2013) Cholinesterase activity in the tissues of bivalves Noah's ark shell (Arca noae) and warty venus (Venus verrucosa): characterisation and in vitro sensitivity to organophosphorous pesticide trichlorfon. Comp Biochem Physiol B 165: 243-249. https://doi.org/10.1016/j.cbpb.2013.05.002

Petrović S, Ozretić B, Krajnović-Ozretić M, Bobinac D (2001) Lysosomal membrane stability and metallothioneins in digestive gland of mussels (Mytilus galloprovincialis) as biomarkers in a field study. Mar Pollut Bull 42:1373-1378

Phillips DJH (1976) The common mussel Mytilus edulis as an indicator of pollution by zinc, cadmium, lead and copper: effects of environmental variables on uptake of metals. Mar Biol 38:59-69. https://doi.org/ 10.1007/BF00391486

Phuong TTM (2014) Bioaccumulation of heavy metals in Nha Trang bay, Khanh Hoa, Viet Nam. Earth Sciences. Université Nice Sophia Antipolis, PhD Thesis, NNT: 2014NICE4058. tel01080132

Pinta M (1980) Spectrométrie d'absorption atomique, application à l'analyse chimique. 2ième édition, Paris

Prato E, Biandolino F, Parlapiano I, Giandomenico S, Denti G, Calo M, Spada L, DiLeo A (2019) Proximate, fatty acids and metals in edible marine bivalves from Italian market: beneficial and risk for consumers health. Sci Total Environ 648:153-163 
Poutiers JM (1987) Bivalves. In: Fischer W, Bauchot ML, Schneider M, editors. Fiches FAO d'identification des espèces pour les besoins de la pêche. (Révision 1). Méditerranée et Mer noire. Rome: food and agriculture Organization of the United Nations, FAO, 369-512p

Prevodnik A, Gardeström J, Lilja K, Elfwing T, McDonagh B, Petrović N, Tedengren M, Sheehan D, Bollner T (2007) Oxidative stress in response to xenobiotics in the blue mussel Mytilus edulis L.: evidence for variation along a natural salinity gradient of the Baltic Sea. Aquat Toxicol 82:63-71. https://doi.org/10.1016/j.aquatox.2007.01.006

Puljas S, Peharda M, Župan I, Bukša F (2015) Maximum recorded life span of Arca noae Linnaeus, 1758 in the marine protected area Telaščica, Adriatic Sea. Cah Biol Mar 56:163-168

Raspor B, Dragun Z, Erk M, Ivanković D, Pavii J (2004) Is the digestive gland of Mytilus galloprovincialis a tissue of choice for estimating cadmium exposure by means of metallothioneins? Sci Total Environ 333:99-108. https://doi.org/10.1016/j.scitotenv.2004.05.008

Richir J, Gobert S (2014) The effect of size, weight, body compartment, sex and reproductive status on the bioaccumulation of 19 trace elements in rope-grown Mytilus galloprovincialis. Ecol Indic 36:3347. https://doi.org/10.1016/j.ecolind.2013.06.021

Rinbio (2001) Evaluation de la qualité des eaux basée sur l'utilisation de stations artificielles de moules en Méditerranée: résultats de la campagne 2000. Ifremer et Ministère de 1'Ecologie et du Développement Durable. $94 p$

Rouane Hacene O, Boutiba Z, Belhaouaria B, Guibbolini-sabatier M, Francour P, Risso-de Faverney C (2015) Seasonal assessment of biological indices, bioaccumulation and bioavailability of heavy metals in mussels Mytilus galloprovincialis from Algerian west coast, applied to environmental monitoring. Oceanologia 57:362374. https://doi.org/10.1016/j.oceano.2015.07.004

Roesijadi G (1994) Metallothionein induction as a measure of response to metal exposure in aquatic animals. Environ Health Perspect 102:91-95

Saha N, Mollah MZI, Alam MF, Rahman MS (2016) Seasonal investigation of heavy metals in marine fishes captured from the Bay of Bengal and the implications for human health risk assessment. Food Control 70:110-118. https://doi.org/10.1016/j.foodcont.2016. 05.040

Spencer KL, MacLeod CL, Tuckett A, Johnson SM (2006) Source and distribution of trace metals in the Medway and Swale estuaries, Kent. Mar Pollut Bull 52:226-231. https://doi.org/10.1016/j. marpolbul.2005.10.019

Staines-Urías F, Douglas RG, Gorsline DS (2009) Oceanographic variability in the southern Gulf of California over the past 400 years: evidence from faunal and isotopic records from planktic foraminifera. Palaeoecol 284:337-354. https://doi.org/10.1016/j.palaeo.2009.10.016

Strizak Z, Ivankovic D, Profrock D, Helmholz H, Cindric AM, Erk M, Prange A (2014) Characterization of the cytosolic distribution of priority pollutant metals and metalloids in the digestive gland cytosol of marine mussels: seasonal and spatial variability. Sci Total Environ 470-471:159-170. https://doi.org/10.1016/j.scitotenv. 2013.09.051

Storelli MM, Marcotrigiano GO (2001) Total mercury levels in muscle tissue of swordfish (Xiphias gladius) and bluefin tuna (Thunnus thynnus) from the Mediterranean Sea (Italy). J Food Prot 64:10581061

Storelli MM (2008) Potential human health risks from metals $(\mathrm{Hg}, \mathrm{Cd}$, and $\mathrm{Pb}$ ) and polychlorinated biphenyls (PCBs) via seafood consumption: estimation of target hazard quotients (THQs) and toxic equivalents (TEQs). Food Chem Toxicol 46:2782-2788. https://doi. org/10.1016/j.fct.2008.05.011

Trabelsi S, Driss MR (2005) Polycyclic aromatic hydrocarbons in superficial coastal sediments from Bizerte lagoon, Tunisia. Mar Pollut Bull 50:344-359

Türkmen A, Türkmen M, Tepe Y, Çekiç M (2010) Metals in tissues of fish from Yelkoma lagoon, northeastern Mediterranean. Environ Monit Assess 168:223-230. https://doi.org/10.1007/s10661-009-1106-3
USEPA (2010) Risk-based concentration table. Region 3. Philadelphia, PA

USFDA (2001) United States Food and Drug Administration, fish and fisheries products hazards and controls guidance. Appendix 5FDA and EPA safety levels in regulations and guidance, 3rd edn

Uluturhan E, Darılmaz E, Kontas A, Bilgin M, Alyuruk H, Altay O, Sevgi S (2019) Seasonal variations of multi-biomarker responses to metals and pesticides pollution in M. galloprovincialis and T. decussatus from Homa lagoon, eastern Aegean Sea. Mar Pollut Bull 141:176-186

Verlecar XN, Jena KB, Chainy GBN (2007) Biochemical markers of oxidative stress in Perna viridis exposed to mercury and temperature. Chem Biol Interact 167:219-226. https://doi.org/10.1016/j.cbi. 2007.01.018

Viarengo A, Ponzano E, Dondero F, Fabbri R (1997) A simple spectrophotometric method for metallothionein evaluation in marine organisms: an application to Mediterranean and Antarctic mollusks. Mar Environ Res 44:69-84. https://doi.org/10.1016/S0141-1136(96)00103-1

Vieira C, Morais S, Ramos S, Delerue-Matos C, Oliveira M (2011) Mercury, cadmium, lead and arsenic levels in three pelagic fish species from the Atlantic Ocean: intra-and inter-specific variability and human health risks for consumption. Food Chem Toxicol 49: 923-932. https://doi.org/10.1016/j.fct.2010.12.016

Viegas CN, Nunes S, Fernández R, Neves R (2009) Streams contribution on bathing water quality after rainfall events in Costa do Estoril- a tool to implement an alert system for bathing water. J Coast Res 56: 1691-1695

Waeles M, Riso RD, Le Corre P (2007) Distribution and seasonal changes of lead in an estuarine system affected by agricultural practices: the Penze estuary, NW France. Estuar Coast Shelf S 74:570-578

Wang WX (2009) Metals and organic contaminants in bivalve molluscs. Shellfish safety and quality. Woodhead publishing series in food science, technology and Nutrition Pages 228-247

Wang Z, Ma X, Lin Z, Na G, Yao Z (2009) Congener specific distributions of polybrominated diphenyl ethers (PBDEs) in sediment and mussel (Mytilus edulis) of the Bo Sea, China. Chemosphere 74:896901. https://doi.org/10.1016/j.chemosphere.2008.10.064

Warwick R (2005) Taxonomic distincness as an indicator of stress in the marine macrobenthos. Indicators of stress in the marine benthos, IOC workshop report No 195:10-11p

Yamaguchi S, Miura C, Kikuchi K, Celino FT, Agusa T, Tanabe S, Miura $\mathrm{T}$ (2009) Zinc is an essential trace element for spermatogenesis. Proc Natl Acad Sci U S A 106:10859-10864. https://doi.org/10.1073/ pnas.0900602106

Yi Y, Yang Z, Zhang S (2011) Ecological risk assessment of heavy metals in sediment and human health risk assessment of heavy metals in fishes in the middle and lower reaches of the Yangtze River basin. Environ Pollut 159:2575-2585. https://doi.org/10.1016/j.envpol. 2011.06.011

Yusa V, Suelves T, Ruiz-Atienza L, Cervera ML, Benedito V, Pastor A (2008) Monitoring program on cadmium, lead and mercury in fish and seafood from Valencia, Spain: levels and estimated weekly intake. Food Addit Contam Part B Surveill 1:22-31. https://doi.org/ 10.1080/19393210802236935

Zaaboub N, Alves Martins MV, Dhib A, Béjaoui B, Galgani F, El Bour M, Aleya L (2015) Accumulation of trace metals in sediments in a Mediterranean lagoon: usefulness of metal sediment fractionation and elutriate toxicity assessment. Environ Pollut 207:226-237. https://doi.org/10.1016/j.envpol.2015.09.033

Župan I, Peharda M, Ezgeta-Balić D, Šarić T (2012) Noah's ark shell (Arca noae Linnaeus, 1758) - what do we need to know for starting up its aquaculture? Croat J Fish 70:71-81

Publisher's note Springer Nature remains neutral with regard to jurisdictional claims in published maps and institutional affiliations. 